\title{
THE USE OF ECONOMIC DATA IN LABOR CASES
}

\author{
DAVm ZrSKIND*
}

\section{INTRODUCTION}

1 THE modern lawyer has added an economist to the staff of experts in his retinue. In the field of labor law, this new attendant has helped to uproot many an old weed and to reset the perennials in a new landscape. The joint efforts of lawyers and economists have been planted in the rows of court briefs and their blooming into judicial decisions has gone unnoticed. It is with the purpose of letting the sun in upon those plants that this article has been written.

In order to obtain a comprehensive review of the manner in which economic data have been treated in the historic sequence of labor cases, the writer has examined the briefs of counsel submitted to the United States Supreme Court in approximately sixty cases involving labor activities and labor laws. ${ }^{x}$ In some instances, it has also been possible to read records of the oral arguments before the court. The alignment of issues and the utilization of economic data in these briefs have been compared with the reasoning of the courts, and a summary of the more obvious interactions is presented below.

In a sense, all of the evidence introduced at the trial of a labor case is economic data because every labor dispute is an economic phenomenon. Some distinction might be made between historical, psychological, biological and economic facts presented in the trial testimony; but they all relate to an economic situation. For the purposes of this article, we have regarded such facts, alleged in the declaration or the complaint, without differentiation, as the narrative facts. They are the facts presented in a case because it is necessary to narrate and prove some facts to maintain a cause of action; they happen to be economic in these cases merely because the field of legal action is economic. This study, however, has been directed toward the economic data which may or may not be introduced within the discretion of the parties, but which are voluntarily presented as a means of assisting the courts in understanding, interpreting, or

* Senior Attorney, United States Department of Labor.

I The writer is indebted to Samuel Barker, an attorney in the United States Department of Labor, for his assistance in the examination of these voluminous briefs. 
evaluating the narrative facts. The former might be called interpretative facts or, as they have been commonly labelled, economic data.

The writer has been interested, not only in the use of interpretative facts, but also in the use of economic references, economic authorities and economic theories. The references may be cited as authorities or cited for whatever additional interpretative facts they may contain. The authorities may be quoted to illustrate the wisdom of an opinion or to demonstrate that a certain idea is common knowledge. The economic theories may be expounded or advocated as inherent in the law or as aids to the proper application of the law. These differences in the character of the material or the technique of handling the material will appear in the course of this article.

The cases considered are discussed herein under the subject headings of (I) Labor's Aggressive Activities-Restraint of Trade, Strikes, Boycotts and Picketing; (2) Labor's Bargaining Activities-Yellow Dog Contracts and Collective Bargaining; (3) Labor Legislation-Hours, Child Labor, and Minimum Wages. Within each subdivision an attempt is made to follow the cases in their chronological order. This review is confined to United States Supreme Court decisions and there is no pretense to a summary of all the principles of labor law; but in order to observe the significance of the economic data discussed, a brief introductory statement of the Supreme Court decisions is given under each heading, and after the use of economic data is presented, a slight excursion is made into related problems likely to come before the Supreme Court.

\section{LABOR'S AGGRESSTVE ACTIVITIES}

\section{RESTRAINT OF TRADE}

The early judicial attitudes toward the activities of organized labor underwent some alteration even before the United States Supreme Court had occasion to rule upon them. The doctrine of criminal conspiracy in its all embracing form, by which all combinations of workers to affect the terms of their employment were deemed criminal, was laid to rest by the lower courts. The declarations on the subject by the United States Supreme Court were in explanation of the modern rule, that what one may do singly, he may do in concert with others as long as both his purpose and methods are lawful. The lower courts had already recognized the complex and impersonal character of modern employment for which they needed new legal theories. But their reliance upon legal theory or upon limited personal observation led to their formulation of new theories of law by which they frequently reached the same result which they had 
previously attained. The new doctrine of malice and just cause became new premises upon which opinions might be evolved with or without attention to the social circumstances of the cases-with varying and inconsistent results.

The United States Supreme Court commenced its series of labor decisions in a world of legal rule and reason which had already developed these definite theoretical premises and abstract techniques of application. In this atmosphere, the first group of labor cases to arise were those brought under the anti-trust laws. The Sherman $\mathrm{Act}^{2}$ provided that every combination in restraint of trade was unlawful. Under that act and the amendments known as the Clayton Act, ${ }^{3}$ strikes and boycotts of labor organizations were made the subject of injunctions and judgments for treble damages.

The Sherman Act was first applied by the United States Supreme Court in a labor dispute in the Danbury Hatters' case. ${ }^{4}$ In that case and in the Bucks Stove and Range case, 5 the Court found that secondary boycotts used with the intention of curtailing the interstate trade of nonunion firms were in violation of the law. The agitation against these and other court decisions restricting the aggressive activities of labor organizations culminated in the adoption of the Clayton Act. That act, incorporating the rubric that the labor of human beings is not a commodity, was heralded by organized labor as its liberation from the Sherman law. The Supreme Court, however, in the Duplex case ${ }^{6}$ held that the Clayton Act did not exempt labor organizations from the anti-trust law and did not legalize the secondary boycott. The next few labor decisions under the anti-trust acts differentiated between proximate and remote interferences with interstate commerce. In the first Coronado Coal Co. case, ${ }^{7}$ a strike to unionize a mining area was held local, indirect and too remote, but upon a retrial of the case and upon the introduction of new evidence connecting the strike with an intent to preserve the union organization in competitive fields, the Court found an immediate and proximate restraint upon interstate commerce. ${ }^{8}$ In the United Leather Workers case, ${ }^{9}$ the

226 Stat. 209 (r89o), I 5 U.S.C.A. $\$$ I (I927).

${ }^{3} 3^{8}$ Stat. 730 (I9I4), I5 U.S.C.A. $\$ \S$ I2, I7, 26 (I927); 38 Stat. 737 (I9I4), 28 U.S.C.A. $\S_{38 \mathrm{x}}(\mathrm{rg} 28)$.

4 Loewe v. Lawlor, 208 U.S. 274 (rgo8).

5 Gompers v. Bucks Stove and Range Co., 22I U.S. 4 I8 (IgIx).

${ }^{6}$ Duplex Printing Press Co. v. Deering, 254 U.S. 443 (r92I).

7 United Mine Workers v. Coronado Coal Co., 259 U.S. 344 (I922).

${ }^{8}$ Coronado Coal Co. v. United Mine Workers, 268 U.S. 295 (Ig25).

9 United Leather Workers Internat'l Union v. Herkert and Meisel Trunk Co., 265 U.S. 457 (1924). 
Court found another strike limited to local restraints. ${ }^{\text {Io }}$ The final labor case of importance which arose under the anti-trust laws was the Bedford Cut Stone case, ${ }^{\text {II }}$ in which the majority court found a boycott essentially the same as in the Duplex case, but in which Justice Brandeis (joined by Justice Holmes in a dissent) sought to demonstrate the reasonableness of the strike and boycott in that case and endeavored thereby to exclude them from the operation of the Sherman Act. ${ }^{\mathrm{I2}}$ In time, the threat of this rule of reason and the increasing availability of injunctions as a legal method of combating organized labor have tended to eliminate proceedings based upon the Sherman and Clayton acts, but these cases remain to illustrate how the realities of economic life were considered or disregarded in labor cases. ${ }^{3}$

The early boycott cases. - The economic issues in these cases were argued and decided without a deliberate use of economic data. ${ }^{14}$ They all raised the question whether acts performed before or after the shipment of goods, with no physical obstruction to the movement of goods, could be a

so The law was next applied to the labor relations activities of employers' associations. In the case of United States v. Brims, 272 U.S. 549 (x926), an agreement among manufacturers and contractors to employ only union carpenters and not to install millwork produced under non-union conditions was held a criminal violation of the Sherman Act. In the case of Industrial Ass'n of San Francisco v. United States, 268 U.S. 64 (I925), a combination to refuse to sell building materials produced in California to those contractors of San Francisco who refused to operate on the open shop plan was held not to restrain interstate commerce. In the case of Anderson v. Shipowners' Ass'n, 272 U.S. 359 (I926), the court upheld the sufficiency of a complaint alleging that a shipowners' association operated a marine service bureau through which members were required to obtain labor and through which workers were compelled to accept employment at fixed wages. These decisions applied the same reasoning to employers' associations as had been applied to the labor organizations.

Ix Bedford Cut Stone Co. v. Journeymen Stone Cutters Ass'n, 274 U.S. 37 (I927).

${ }^{2}$ Id. at $5^{6-65}$.

${ }^{13}$ In these cases, the Court ruled upon numerous questions of law such as the intention of Congress to include labor organizations under the Sherman Act, the meaning of restraint of trade, the nature of interstate commerce, the extent to which Congress intended by the Clayton Act to exempt labor organizations from the anti-trust law or from the power of the courts to grant injunctions, the intent required for restraint of trade under the law and the applicability of the law to reasonable restraints. It is not the purpose of this article to review the holdings of the Court on these questions. In the course of deciding these points of law, the Court made certain determinations of fact and was guided by certain general appraisals of economic conditions. Also in applying the general doctrines, the Court rested upon certain findings of fact. Frequently, one rule of law or another could have been invoked, with contrary results, depending upon how the Court envisaged the facts of the case. It is with those situations and the actual or possible use of economic data that the writer has been concerned. Consequently, the following remarks concerning the restraint of trade cases do not purport to exhaust the issues involved, but relate only to the use of interpretative economic material in those cases.

${ }^{14}$ See Briefs in Case No. ${ }_{389}$, Oct. Term 1907 ; Appellant's Brief in Case No. 45, Oct. Term

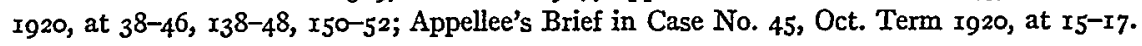


restraint of interstate commerce. Purely as a matter of statutory construction, the court decided that such conduct was actionable when it involved an intent to restrain interstate commerce. Although few, if any, interpretative facts were presented, the court had no hesitation in finding such an intent in the cases before it. The popular issue of whether the Clayton Act was designed to free labor organizations from the Sherman Act was treated as a psychological problem of Congressional intent with little recognition of the labor conflict involved. So the exemption of labor unions from the injunctive process was limited to disputes between an employer and his immediate employees without a discussion of the facts of the employment situation. The relationships between the parties and the strangers to the boycotts were discussed only in general terms, and the legal concepts of coercion and liberty prevailed.

The Coronado Coal Co. cases.-These cases, involving essentially the same narrative facts, illustrate well the effectiveness of economic data. In the first case, the record ${ }^{x s}$ disclosed the basic facts.

The manager of the Bache-Denman Mines decided to change from union to open shop operation. Guards were hired and armed. One mine was surrounded with cable entanglements. Some of the mines were closed in order to reopen non-union. The district organization of the workers called a strike. A delegation to the superintendent was followed by a crowd which rioted, injured the guards, and destroyed property. At another mine later, there was a gun battle, the mine was dynamited and destroyed and two guards were taken out and murdered.

The Court found an intention to prevent the operation of the mines with non-union labor but no intention to affect interstate commerce. The strike was said to be local in origin, motive, waging and felonious ending. At the trial of the second case, however, the company introduced new evidence. ${ }^{16}$

In convention proceedings and private discussion, union leaders stressed the danger of non-union competition from Southern Colorado, Alabama and Tennessee to the union agreements in Arkansas, Oklahoma and Texas, and the determination of the unionists to prevent the shipment of coal from the open shop Coronado mines in competition with union mines. The potential output in the Coronado mines was more fully established as 5000 tons a day instead of 5000 tons a week, as previously assumed; and the possibility of cheaper production and lower prices was proved, in order to show what the union really feared.

In their briefs, ${ }^{17}$ the company's attorneys took full advantage of the general economic background in the case. They emphasized the potential

${ }^{15}$ See Record and Briefs in Case No. 31, Oct. Term r9Ig.

${ }^{26}$ See Record and Briefs in Case No. 671, Oct. Term r924.

${ }^{27}$ See Brief for Pl. in Error in Case No. 671, Oct. Term 1924, at 21, 22, 50, 54 and Appendix. 
production of the plaintiff's mines and its possible influence upon the price of coal in the competitive market. In order to remove all doubt about their ability to undersell union mines, they tabulated in an appendix the reasons given by their expert witnesses for the cheaper production of coal in open shop mines. Then they argued the general policy of the union to increase the price of coal in one area to protect union operators elsewhere and they inferred an intention to restrain interstate commerce in this case because of the importance to the union of preventing the plaintiff's open shop operations and shipments in interstate commerce. They even recognized that the doctrine of restraint of trade might be limited by the reasonableness of the restraint, and they argued that the commission of crimes to damage a competitor could not be considered reasonable. The attorneys for the Coronado Company presented a convincing argument because of their accumulation of new evidence showing the economic circumstances surrounding the parties.

The union's brief ${ }^{18}$ attempted to show that the workers' acts were concerned with the purely local matters of personal self-defense and the preservation of the company's union agreement, but the reality of the union's interest in protecting its organization throughout the coal areas of the United States was too stark to conceal.

The Supreme Court overruled portions of the lower court decisions on the basis of the economic data in the case. The new evidence of the threat to unionization across state lines and of the recognition and discussion of it by the union officials was deemed sufficient to require the submission of the question of the union's intention to a jury. The Supreme Court held that the mere reduction in the supply of coal to be shipped in interstate commerce, even by tortious or criminal conduct, would ordinarily be too remote and indirect to constitute a restraint upon interstate commerce, but the addition of an intent to control the supply entering and moving in interstate commerce or to control the price of coal in interstate markets, in order to protect union producers, would make the action of the local union officials a direct violation of the anti-trust act. The Court's conclusion that there was sufficient evidence of such an intent to warrant a new trial was made possible by the powerful factual presentation of the company's case. ${ }^{19}$

Bedford Cut Stone Co. v. Journeymen Stonecutters Ass'n of N.A. ${ }^{20}$-In this case, the minority decision of Justice Brandeis, without aid of counsel, demonstrated to what end economic data might be directed in

${ }^{18}$ See Brief for Def. in Error in Case No. 67x, Oct. Term I924.

${ }^{19}$ See Brief for Pl. in Error in Case No. 67x, Oct. Term I924. $\quad{ }^{20} 274$ U.S. 37,56 (1927). 
restraint of trade cases. The briefs ${ }^{2 x}$ of both sides were devoid of interpretative facts. The majority court found that the union, by resolving not to finish the cutting of any stone started by non-union men, and by inducing strikes thereon upon distant jobs, conducted a secondary boycott with an intent to interfere with interstate commerce. ${ }^{22}$ Justice Brandeis built an imposing minority opinion by restating the evidence and by extracting from it economic implications calculated to bring the case within the scope of the legal principle that the Sherman Anti-Trust Law did not prohibit reasonable restraints of trade.

He observed that the plaintiffs were not isolated weak employers but the producers of seventy per cent of the cut stone shipped in the interstate commerce of the country. They were organized in a local employers' association and affiliated with a national cut stone association. On the other hand, the defendants' organization had only I50 locals averaging thirty-three members each and its strength depended upon the combination and loyalty of all of its 5,000 members dispersed throughout the country. The conflict was made to appear one between organizations of employers and employees necessarily national in scope. Justice Brandeis differentiated this case from the other restraint of trade cases by stressing the fact that the workers here endeavored merely to have the members of their own craft and organization refuse to finish products started by opponents of their organization. They sought no action by outsiders and no boycott of outside dealers or contracts; nor did they engage in any unlawful trespasses, breaches of contract, violence, intimidation, fraud, or threats. Upon these facts, he concluded that the case involved merely a refusal to work against one's self-interest, in a struggle between an organization of employees and an organization of employers within their own trade, and that to deny such workers the right to cease work under those circumstances reminded one of involuntary servitude. He rested this view of the case upon a legal principle, namely, the limitation of the Sherman Law to unreasonable restraints of trade, which was not disowned by the majority court. The briefs of counsel were of practically no assistance in building this interpretation of the facts of the case, but Justice Brandeis indicated clearly what use could have been made of economic data in this case and per example what might be done in other cases.

The doctrine of restraint of trade is still the law. ${ }^{23}$ It has been little

${ }^{2 x}$ See Briefs in Case No. 4r2, Oct. Term ra26.

${ }^{22}$ Justices Sanford and Stone concurred because of the controlling effect of the earlier Duplex decision.

${ }_{23}$ United States v. Local No. 167, 29 r U.S. 293 (1934) applied the Sherman Act to a labor racket. 
used in recent labor disputes because other legal weapons have been found more valuable. Still, it influences many judicial decisions in the subtle manner of pervading legal concepts and may at any time be offered as the sole basis for determining a labor dispute. The existence of an intent to restrain interstate commerce may be decided as it was in the second Coronado Coal Co. case by proof of the general economic background behind the activities of the parties. In defense, the rule of reason, now firmly entrenched in the law of monopolies, may be urged with renewed vigor and the question of reasonableness may be decided or at least influenced by economic data.

\section{STRIKES}

The decisions of the Supreme Court under the Sherman and Clayton acts passed upon the legality of strikes only in so far as they involved a restraint upon interstate commerce. Whenever the court found such a restraint, the strike, being part of the combination to accomplish that restraint, was declared unlawful. There was no consideration of the strike or the right to strike aside from the other activities of the workers. There was a definite avoidance of the factual data submitted to demonstrate the proper purposes of the strike. The majority court found that regardless of the legality or illegality of the workers' conduct at common law, their intent to restrain interstate commerce vitiated all of their joint acts under the anti-trust laws. Justice Brandeis, in his minority opinions in the Duplex and Bedford cases, expressed dicta concerning the justification of self-interest in strikes, but the majority opinions were silent on that point. ${ }^{24}$ The restraint of trade cases, particularly if modified by the rule of reason, have failed to establish any basic law of strikes.

Shortly before the Bedford decision, the United States Supreme Court ruled upon the legality of a strike in the case of Dorchy $v$. Kansas. ${ }^{25}$ The object of that strike was to recover an alleged deficiency in wages due one of the union members who had been seeking to collect for over two years and who had left his employment before the strike. The briefs ${ }^{26}$ of counsel argued the constitutionality of the Kansas compulsory arbitration statute and discussed the theories of the right to strike, but offered no

\footnotetext{
24 Nor may it be inferred from the fact that the court refused to take action against strikes involving no intent to restrain interstate trade that the court upheld the legality of such strikes, because in the absence of a violation of the federal anti-trust laws, the federal courts may have had no jurisdiction to proceed any further.
}

25272 U.S. 306 ( 1926$)$.

${ }^{26}$ See Briefs in Case No. II9, Oct. Term I926. 
interpretative data on the peculiar facts of this case. The Court found the strike an unlawful substitute for a lawsuit and commented:

The right to carry on business-be it called liberty or property-has value. To interfere with this right without just cause is unlawful. The fact that the injury was inflicted by a strike is sometimes a justification. But a strike may be illegal because of its purpose, however orderly the manner in which it is conducted. To collect a stale claim due a fellow member of the union who was formerly employed in the business is not a permissible purpose. ${ }^{27}$

The court concluded with a general statement to the effect that "Neither the common law, nor the Fourteenth amendment confers the absolute right to strike." ${ }_{28}$ The limitations upon this right mentioned in the decision were the requirement of "just cause" and a "permissible purpose." Clearly such evaluations as "just cause" or "permissible purpose" can be applied properly only upon a thorough understanding of the social and economic implications of a particular strike. To convey such an understanding to a court, economic briefs may find considerable use.

To a certain extent, the National Labor Relations Act $^{29}$ has clarified the "permissible purposes" of strikes by affirming the rights of workers to organize, select representatives of their own choice, bargain collectively and act concertedly for mutual aid and protection, with an express stipulation that closed shop agreements between employers and the representatives of a majority of workers in an appropriate bargaining unit are legal. Under this statute, the Supreme Court has already had occasion to acknowledge the rights of workers in strikes for improvements in wages, hours, and other conditions of employment, ${ }^{30}$ for an opportunity to bargain collectively, ${ }^{35}$ for an all union shop, ${ }^{32}$ and for the reinstatement of workers against whom the employer discriminated. ${ }^{33}$ The use of economic data in these cases is reviewed below. The real purpose of a strike must still be proved and the significant circumstances will call for interpretative data.

\section{BOXCOTIS}

The restraint of trade decisions were a little more explicit on the legality of boycotts than they were on strikes. Although the court repeatedly

${ }^{27} 272$ U.S. 306, 3 II (I926).

${ }^{28} \mathrm{Id}$. at $3 \mathrm{Ir}$.

${ }^{29} 49$ Stat. 449 (I935), 29 U.S.C.A. $\$$ I5 (I927).

${ }^{30}$ Santa Cruz Fruit Packing Co. v. N.L.R.B., 303 U.S. 453 (r938); N.L.R.B. v. Mackay Radio \& Telegraph Co., 304 U.S. 333 (1939); N.L.R.B. v. Fansteel Metallurgical Corp., 59 S. Ct. 490 (1939); N.L.R.B. v. Sands Manufacturing Co., 59 S. Ct. 508 (1939).

${ }^{3 x}$ Santa Cruz Fruit Packing Co. v. N.L.R.B., 303 U.S. 453 (x938).

${ }_{32}$ N.L.R.B. v. Columbian Enameling \& Stamping Co., 59 S. Ct. 5 or (1939).

33 N.L.R.B. v. Sands Manufacturing Co., 59 S. Ct. 508 (r939). 
stated that the applicability of the anti-trust laws depended upon the intent to restrain interstate commerce and not upon the legality or illegality of boycotts under the common law, the court took occasion to note that the cases involved secondary boycotts unlawful in the states where they occurred and that the Sherman and Clayton Acts did not legalize secondary boycotts.

In the Duplex case, the employers' brief ${ }^{34}$ argued that a boycott was a conspiracy depriving the public-an innocent party-of its sovereign right of choice over commodities and therefore, unlike a strike, it was not an ordinary effort of a labor organization to improve its conditions of employment. The majority court construed the Clayton Act as protecting organized labor only in its lawful pursuits and the court found no congressional intent to legalize the secondary boycott. ${ }^{35}$ The minority court ${ }^{36}$ declared that the union boycott was not unlawful at the common law because it was in the workers' self-interest. Just as strikes and the refusal to handle non-union materials had been justified, so this boycott by the employees of unionized firms against a non-union competitor should be justified as a competitive injury inflicted in their self-interest.

In the Bedford case, the majority court found a secondary boycott like that in the Duplex case and held it also a restraint of trade..$^{37}$ Though counsel for the union offered no interpretative data, ${ }^{38}$ Justice Brandeis insisted that the union members sought no action by outsiders, no boycott of outside dealers or contractors and that surely in such a case the self-interest of the unionists justified their conduct. ${ }^{39}$

Although these decisions have been cited frequently to indicate that the United States Supreme Court has held secondary boycotts unlawful, they hold at most that when a secondary boycott is deemed unlawful in the state in which it occurs, it will not be regarded as lawful by the Supreme Court, and when it is accompanied by an intention to restrain interstate commerce in violation of the anti-trust laws, it will be held an unlawful combination in restraint of trade. The many problems connected with the law of boycotts such as whether other union members, public sympathizers or consumers may instigate the boycott, whether other products of an "unfair" employer or politically undesirable goods may be boy-

34 See Appellant's Brief in Case No. 45, Oct. Term rg2o.

35 Duplex Printing Press Co. v. Deering, 254 U.S. 443 (I92I).

${ }^{36} \mathrm{Id}$. at $479-88$.

37 Bedford Cut Stone Co. v. Journeymen Stone Cutters Ass'n, 274 U.S. 37 (1927).

${ }^{38}$ See Brief for Union in Case No. 4I2, Oct. Term I926.

39 Bedford Cut Stone Co. v. Journeymen Stone Cutters Ass'n, 274 U.S. 37, 59 (I927). 
cotted, and whether newspaper advertisers, remote retailers or ultimate consumers may be boycotted have not been settled by state courts. In keeping with recent trends in labor law, even the attitude toward secondary boycotts is undergoing a change in many states. ${ }^{40}$ In this uncertain and shifting field of law, economic data may play a determinative role.

\section{PICKETING}

The Supreme Court decisions on picketing have been much more direct than those on boycotts. In the American Steel Foundries case, ${ }^{4 \mathrm{~T}}$ the court proceeded cautiously to define the nature of proper and improper conduct. It denounced the obvious acts of assault and disapproved of the intimidation resulting from the presence of large numbers after such acts. Avoiding the use of the term picketing, it permitted the patrol of each place of ingress and egress by one representative of the workers who might seek to persuade without coercion. On the same day on which that case was decided, the Court, in the Truax case, ${ }^{42}$ found that if the courts of Arizona refused to grant an injunction against picketing with libelous signs and intimidatory remarks because of a state law ${ }^{43}$ limiting injunctions in labor disputes, that law was unconstitutional. Picketing by illegal means, even though peaceful, could not be sheltered from the injunctive process of the courts.

Several years later, Congress adopted the Norris-LaGuardia Act ${ }^{44}$ prohibiting the issuance of injunctions against an enumerated list of peaceful activities in labor disputes. Many states enacted laws patterned after this and in the Senn case, ${ }^{45}$ the Court upheld the constitutionality of the Wisconsin statute. $4^{6}$ That case involved the peaceful picketing of a tile setting contractor, by persons not his employees, for the purpose of inducing him to sign an agreement to unionize his shop and to refrain from working as a tile setter himself. In the Lauf case, ${ }^{47}$ the Court held that the picketing of a company's grocery and meat markets by a union, embracing none of the company's employees, for the purpose of obtaining recognition and collective bargaining was peaceful conduct in a labor dispute protected by both federal and state acts from injunctive restraint. This time a minority court dissented $4^{8}$ on the interpretation of a labor dispute

\footnotetext{
10 6 Internat'l Juridicial Ass'n Bull., Secondary Boycotts in Labor Disputes, $\$ 7$ at 83 .

${ }^{4}$ American Steel Foundries Co. v. Tri-City Central Trades Council, 257 U.S. I84 (xg21).

42 Truax v. Corrigan, 257 U.S. 3 I2 (I92I).

43 Ariz. Rev. Stat. I913, If I164.

${ }_{14} 47$ Stat. 72 (1932), 29 U.S.C.A. \$ Ior (Supp. 1938).

45 Senn v. Tile Layers Protective Union Local No. 5, 30r U.S. 468 (I936).

${ }^{46}$ Wis. L. 193r, c. 376 ; Wis. L. I935, c. 55 r.

${ }_{47}$ Lauf v. Shinner \& Co., 303 U.S. 323 (1938).

${ }^{48} I d$. at $33^{I}$.
} 
under the acts and insisted that an injunction should lie against what appeared to it to be fraudulent, intimidatory and coercive conduct of strangers to the employer-employee relationship. The majority court, however, again placed a liberal construction upon the term "labor dispute" under the Norris-LaGuardia Act in the New Negro Alliance case. ${ }^{49}$ It reversed an injunction against the peaceful picketing of a grocery company by a civic organization of Negroes, which organization included none of the company's employees and which organization sought to induce the company to engage Negroes as clerks instead of merely as menials. Despite a minority opinion which regarded such picketing as "mobbish interference" with individual liberty,,$^{\circ}$ the right to picket peacefully and to be free therein from the injunctive control of federal and certain state courts seems firmly established. The presence or absence of economic data in these cases presents many suggestions for the use of such material in similar situations.

American Steel Foundries v. Tri-City Central Trades Council; Truax v. Corrigan.-In neither of these cases did the briefs of counsel offer economic data..5x They urged the adoption of certain economic and legal convictions such as that all picketing is a nuisance, that labor discontent must express itself in either picketing or anarchy, that all peaceful activities of labor organizations should be lawful, that property in the good will of a business does not deserve the absolute protection given tangible property, that free speech and publication are more sacred than the right to conduct business and that pickets should have the same immunities as commercial competitors of the employer. In so far as any authorities were cited in support of these subjective evaluations, they were judicial decisions and not the studies or conclusions of economists. That may help explain why the court limited picketing so unrealistically to one missionary at each place of ingress and egress, and insisted upon preserving the injunctive power of the courts over peaceful picketing.

Senn v. Tile Layers Protective Union.-The brief ${ }^{52}$ of counsel for Senn consisted of a legal argument on the deprivation of his property without due process of law and the denial of equal protection of the law. The brief $^{53}$ of counsel for the union, however, supplemented its legal argument with an extensive discussion of the economic relationship of the parties. It alluded to narrative and interpretative facts submitted in evidence at

\footnotetext{
49 New Negro Alliance v. Sanitary Grocery Co., 303 U.S. $55^{2}$ (1938). so Id. at $56_{3}-4$. sx See Briefs in Case No. 2, Oct. Term I921; Briefs in Case No. 13, Oct. Term I92r. $5^{2}$ See Brief for Pl. in Error in Case No. 658, Oct. Term 1936. 53 See Brief for Def. in Error in Case No. 658, Oct. Term I936.
} 
the trial of the case and upon them it elaborated the following economic discourse. Just as it was to the interest of the union to displace nonunion men with union men, it was to their interest to prevent a contractor from plying the trade of a tilesetter himself. A contractor working with the tools of his trade may underbid those who do not do so and thereby undermine the business and the wages of the union contractors. The rule against such work was also necessary to prevent a resort to the subterfuge of a partnership between employer and employee, a practice which would bring destruction to the unions and demoralization to the industry. Even independently of the proposed agreement, the contractor would not be permitted to work himself because he had never served an apprenticeship and was not a qualified craftsman, which requirements had long been recognized as legitimate. The union sought to enforce these rules merely by peaceful picketing which was a lawful form of appeal to the public not to patronize the contractor; the contractor was free to use all lawful means at his command to convince the public to trade with him as a nonunion contractor; and the public was free to accept or reject either appeal. Their dispute was just a legitimate economic conflict for employment or trade on conditions suitable to the economically dominant person. The brief tried to bolster this argument with a large number of legal citations on incidental points; but it spun the cloth from threads of fact and theory not found in legal doctrine.

Nevertheless, the United States Supreme Court accepted the theories and argument of the brief and embodied them in its decision. It acknowledged as conclusive the finding of the state Supreme Court that the case involved a labor dispute under the state act. It held that peaceful picketing, permitted by the state law, was not a violation of the Fourteenth Amendment; nor was the union rule requiring Senn to abstain from working as a tile setter. The Supreme Court quoted the state court's finding that the rule was adopted by the defendants out of the necessities of employment within the industry and for the protection of themselves as workers and craftsmen in the industry. "That finding," it held, "is amply supported by the evidence." ${ }^{4}$ The Court went further to declare that "nothing in the federal constitution forbids unions from competing with non-union concerns for customers by means of picketing as freely as one merchant competes with another by means of advertisements in the press, by circulars, or by his window display." 55 This was a new application of the doctrine of laissez faire in labor cases.

54 Senn v. Tile Layers Protective Union Local No. 5, 30r U.S. 468, 480 (I936).

$55 I d$. at $48 \mathrm{I}$. 
Lauf v. E. G. Shinner Eo Co.-Counsel for the union in this case depended so much upon the Senn decision that they presented no interpretative data. ${ }^{56}$ Opposing counsel sought either to differentiate the two cases on logical grounds or to have the doctrine of the Senn case modified. ${ }^{57}$ Similarly the majority and minority courts divided on differences limited to the narrative facts and principles of law.

New Negro Alliance v. Sanitary Grocery Co.-The brief filed for the New Negro Alliance urged upon the court the importance of considering social and economic principles. ${ }^{58}$ Then it set forth data concerning the economic plight of the Negro. These facts showed that Negroes were on relief in greater proportion than Whites and were not being reabsorbed into private industry at the same rate as the Whites, and that the Negro was denied economic opportunities even in federal government employment where he was denied civil service priorities and confined to jobs in the lower paid occupations. Since the Negro had no control over jobs through the ownership of business, the brief argued he was compelled to campaign through negotiations and picketing to obtain economic opportunities for members of his race from those concerns which depend upon Negro patronage. Negotiations having proved fruitless in the instant case, peaceful picketing was indispensable. The brief for the company ${ }^{59}$ ignored this argument and its supporting data and relied on the plea that the dispute was a racial one rather than a labor dispute.

The majority court held that even a racial dispute, arising out of discrimination in the terms or conditions of employment, was a labor dispute. The minority opinion found this construction "tortured" and surmised that now "no employer-merchant, manufacturer, builder, cobbler, housekeeper or what not-who prefers helpers of one color or class can find adequate safeguard against intolerable violations of his freedom."6o Although the majority court may have been influenced by the economic

${ }^{56}$ See Brief for Pl. in Error in Case No. 293, Oct. Term 1937.

57 See Brief for Def. in Error in Case No. 293, Oct. Term 1937.

58 "This case involves not only legal questions but complex socio-economic principles which command the critical attention of all who believe that the law is really sovereign when it ripens into social justice. 'An avalanche of decisions by tribunals great and small is producing a situation where citation of precedent is tending to count for less, and appeal to an informing principle is tending to count for more' (Cardozo, The Growth of the Law). . . . . Comparative study of the size, strength, financial resources, history, purpose, influence, and skill of each contestant is essential. Differences within the economic and social areas should be considered and decisions reached based upon these subtle, yet powerful considerations."-See Brief for Pl. in Error in Case No. 51x, Oct. Term r937.

${ }^{59}$ See Brief for Def. in Error in Case No. 51r, Oct. Term 1937.

60 New Negro Alliance v. Sanitary Grocery Co., 303 U.S. $55^{2}$ (1938). 
data presented by counsel, it failed to acknowledge it as vehemently as the minority justices.

These cases have developed the law of picketing to a point at which peaceful picketing seems assured an immunity from injunctive interference by federal and some state courts. There remain many problems unsettled. What constitutes peaceful picketing must always remain a question of fact. How many pickets may walk together, what sound devices may they use to convey their message, where may the pickets patrol, whom may they accost and what may they say, remain subject to interpretation under the general rules of fraud, intimidation and coercion. That consumers may picket, was implied, but not expressly determined, in the New Negro Alliance case. May picketing be directed against advertisers in allegedly "unfair" newspapers, against dealers in objectionable foreign goods, against exorbitant landlords, against political opponents? These and other problems to arise in new situations will be settled by our courts only upon some interpretation of the social setting in which they appear.

\section{IABOR'S BARGAINING ACTIVITIES}

I. THE RECORD OF LITIGATION

The early efforts of organized labor to bargain collectively were repulsed by many employers through the requirement that employees sign an agreement promising not to become members of a labor organization. To overcome this opposition, the trade unions succeeded in obtaining several statutes against such "yellow dog contracts." In the Adair case, ${ }^{6 \mathrm{x}}$ the Supreme Court declared a federal law ${ }^{62}$ prohibiting anti-union employment contracts on interstate railroads unconstitutional as a curtailment of the liberty of contract. In the Coppage case, ${ }^{63}$ the majority court applied the same reasoning and ruled a Kansas statute unconstitutional. ${ }^{64}$ Justice Day dissented on the ground that this law expressly prohibited coercive contracts and the determination of the state legislature and state supreme court that coercion existed should not be overruled..$^{65}$ The majority court, however, went even one step further in the Hitchman Coal and Coke Co. case,${ }^{66}$ in which it protected a "yellow dog contract" by enjoining

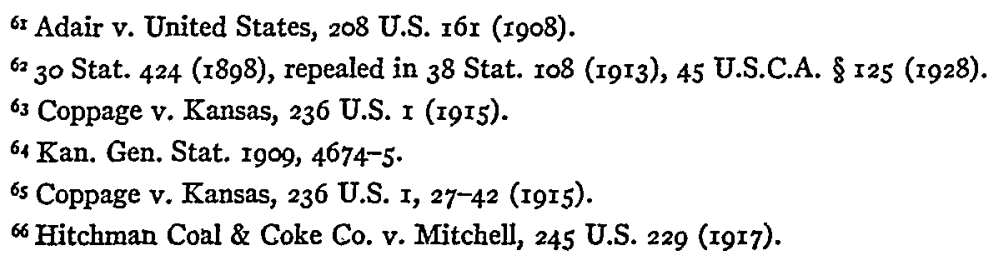


a trade union from seeking to organize the workers who had executed the contract.

In the face of these determinations and in response to the unrelenting pressure of trade unions, Congress enacted the Railway Labor Act of I $926^{67}$ which prohibited all employer interference in the organization of employees on interstate railroads. This time, the Supreme Court, in the Texas and New Orleans Railroad case, ${ }^{68}$. upheld the constitutionality of the Act as a means of eliminating disputes likely to obstruct interstate commerce. The court sought to distinguish the Adair and Coppage cases by glossing over the effect of the Railway Labor Act and holding that it did not prevent the discharge of an employee. Later, in the Virginia Railway case, ${ }^{69}$ the court held that the Railway Act not only prohibited employer interference in the repair shops, but also required an affirmative effort to bargain with the union representatives of a majority of the employees.

Congress extended the rights of collective bargaining in the National Labor Relations Act which expressly forbids discrimination in hiring, discharge or tenure of employment in order to induce an employee to join or to refrain from joining a labor organization, forbids agreements having the same effect and makes collective bargaining the duty of all employers engaged in interstate commerce or in the production of goods affecting interstate commerce. ${ }^{70}$ The Supreme Court has sustained the constitutionality of this act as applied to businesses engaged in interstate commerce such as a motor bus line $\mathrm{e}^{7 \mathrm{x}}$ and a news service ${ }^{72}$ and businesses affecting interstate commerce such as a steel corporation, ${ }^{73}$ a clothing company, ${ }^{74}$ a producer of trailers, ${ }^{75}$ a public utility ${ }^{76}$ and a fruit packing and canning company..$^{77}$ It has held unlawful and enjoined employer interference, coercion and restraint upon the self organization of employees ${ }^{8}$ and employer domination and control of labor organizations. ${ }^{79}$ It has

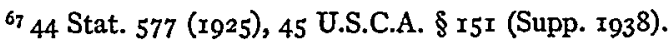

68 Texas \& N. O. Ry. Co. v. Brotherhood of Ry. \& S. S. Clerks, 28I U.S. 548 (1930).

${ }^{69}$ Virginian Ry. Co. v. System Federation No. 40, 300 U.S. 5I5 (1937).

7o $\$ \S 7$ and 8 of the National Labor Relations Act.

${ }^{7}$ Washington, Virginia \& Maryland Coach Co. v. N.L.R.B., 30I U.S. 442 (1937).

${ }^{2}$ Associated Press v. N.L.R.B., 30r U.S. 103 (r937).

${ }_{73}$ N.L.R.B. v. Jones \& Laughlin Steel Corp., 3or U.S. I (1937).

${ }_{44}$ N.L.R.B. v. Friedman-Harry Marks Clothing Co., 301 U.S. $5^{8}$ (1937).

${ }_{75}$ N.L.R.B. v. Fruehauf Trailer Co., 301 U.S. 49 (I937).

${ }^{6}$ Consolidated Edison Co. of N.Y. v. N.L.R.B., 304 U.S. 555 (1939).

7 Santa Cruz Fruit Packing Co. v.N.L.R.B., 303 U.S. 453 (1938).

${ }^{78}$ See cases cited in notes $7 \mathrm{I}-77$ supra.

79 N.L.R.B. v. Pacific Greyhound Lines, Inc., 303 U.S. 272 (I938); N.L.R.B. v. Pennsylvania Greyhound Lines, Inc., 303 U.S. 26I (1938). 
ordered employers to reinstate employees wrongfully discharged or discriminated against because of union activities ${ }^{80}$ and to disestablish company unions. ${ }^{8 I}$ It has protected the right of employees to designate repsentatives of their own choice for the purposes of collective bargaining. ${ }^{82}$ Without ever admittedly reversing the decisions in the Adair and Coppage cases, the United States Supreme Court has arrived at an opposite conclusion-upholding a statute which affirmatively promotes union organization and collective bargaining. This transformation has come about through a pronounced change in public information and political opinion, some of which was brought to the attention of the court as economic data in the briefs presented to it.

2. USE OF ECONOMIC DATA IN THE "YELIOW DOG" CONTRACT CASES

There was no effort to utilize economic data in these early cases. The parties argued freely many economic assumptions and contentions; but interpretative facts were not deemed necessary. In the Adair case, the obstruction of interstate commerce by strikes was alleged and denied without factual proof on either side. ${ }^{83}$ In the Coppage case, the economic coercion arising out of the circumstances of employees seeking jobs was discussed in the abstract. ${ }^{84}$ In the Hitchman case there was considerable argument to decide whether the union was seeking to enlarge its membership or seeking to call a strike and whether agreeing to join a union was the same as joining it. The narrative facts of each case were evaluated in relation to their general significance, but there was no aid sought from authoritative research or expert opinion. ${ }^{85}$ In such a situation the liberty of the employee to contract on terms set by the employer was declared the law.

3. USE OF ECONOMIC DATA IN THE RAILWAY LABOR ACT CASES

These cases involved a little economic data, but no effort to stress its use. The Texas and New Orleans Railroad case briefs ${ }^{86}$ quoted from legislative committee reports and from government studies of railroad strikes to show the past experience of the railroads with voluntary standards; and, upon that record, the court decided that the provisions of the 1926 Railway Labor Act were mandatory. The court conveniently ignored the discharge of union officials and distinguished the Adair and Coppage cases

${ }^{80}$ See cases cited in notes 7 $7-75,77$ supra; also N.L.R.B. v. Mackay Radio \& Telegraph Co., 304 U.S. 333 (1938).

${ }^{82}$ See cases cited in note 79 supra. $\quad{ }^{82}$ See cases cited in notes 76 and 79 supra.

${ }_{3}$ See Briefs in Case No. 293, Oct. Term 1907.

84 See Briefs in Case No. 48, Oct. Term I9r4.

85 See Briefs in Case No. Ix, Oct. Term Igr 7.

${ }^{86}$ See Briefs in Cases No. 469 , Oct. Term rg29. 
on the basis that the Railway Labor Act in protecting unions from employer interference did not interfere with the normal exercise of the carriers' right to hire and fire. In the Virginian Railway case the effect of "back shop" work upon interstate commerce was established by economic data. The employer's brief ${ }^{87}$ described the local repair and manufacturing nature of the work. The employees' brief ${ }^{88}$ showed the interdependence in pay scales, seniority lists, apprentices and transfers between road and shop service; and the government brief ${ }^{89}$ added the fact that the repairmen on the roads and in the shops were united in one organization and would act as a unit in all disputes. The paralysis of interstate commerce in shopmen's strikes was portrayed from past experience, Although the interstate commerce issue was decided on these facts, other more controversial, perhaps more significant, issues were decided without such data. The court held that the employer was required to co-operate with the majority union in a reasonable effort to compose their differences, that the employer was prohibited from bargaining with a minority union and that a majority vote of all workers voting, even though less than a majority of those eligible to vote, was sufficient to designate the representatives of the majority of the workers-all this without the benefit of economic data.

4. USE OF ECONOAIC DATA IN THE NATIONAL IABOR RELATIONS BOARD CASES

The use of economic data in the first five cases arising under the $\mathrm{Na}$ tional Labor Relations Act was consciously planned. The National Labor Relations Board established a Division of Economic Research for the express purpose of preparing such material. This Division made elaborate industrial studies and assisted the attorneys for the Board in the selection and presentation of labor economists as expert witnesses. The interpretative data obtained by this Division came to the United States Supreme Court in both the transcripts of the Board's hearings and in the briefs of the Board's attorneys. The testimony of expert labor economists offered to the Board in the Jones and Laughlin case was reprinted as an official bulletin of the Board, ${ }^{90}$ presented to the members of the Supreme Court during an oral argument and referred to in the briefs of the Board and occasionally in the briefs of counsel for employers.

An outstanding use of the industrial research of the Board's economists

${ }^{87}$ See Briefs for Petitioner in Case No. 324, Oct. Term 1936 at 38-62.

${ }^{88}$ See Brief for Respondent in Case No. 324, Oct. Term 1936, at 77-84.

${ }^{89}$ See Brief for the United States, as amicus curiae in Case No. 324, Oct. Term 1936.

90 National Labor Relations Board, Bull, No. I, Governmental Protection of Labor's Right to Organize. 
was made in demonstrating all the ramifications of the employers' operations in interstate commerce. Such evidence was largely incontrovertible, and the Board's findings incorporating the evidence, made their way into the decisions of the Supreme Court without dispute. Economy of space limits us to a statement of the facts in the Jones and Laughlin case.

a) The Jones and Laughlin Steel Corporation was a mammoth producer of pig iron and steel with properties and transportation facilities in many parts of the country. It was engaged in the manufacture of pig iron and steel in Pittsburgh and Aliquippa, Pennsylvania; it fabricated structural steel in Long Island City, New York and New Orleans, Louisiana; it exploited iron mines in Michigan and Minnesota and carried the ore across the Great Lakes in its four steamships; it quarried limestone in Pennsylvania and West Virginia; it operated coal mines in Pennsylvania and hauled the coal on its own barges and towboats down the Mississippi or on its two railroads which were connected with three large Eastern common carriers; it stored its products in warehouses in Chicago, Detroit, Cincinnati and Memphis; it owned a distributing agency for supplies and equipment for oil wells, pipelines and oil refineries; it had sales offices in twenty American cities from coast to coast and a subsidiary for sales in Canada. All of this was introduced in evidence before the Board and presented pictorially in an illustrated map in the Board's brief before the Supreme Court. The Jones and Laughlin Steel Corporation employed 33,000 men in mining ore, 44,000 in mining coal, 4,000 in quarrying limestone, 16,000 in manufacturing coke, 343,000 in manufacturing steel, and 83,000 in transporting its products. Approximately seventy-five per cent of its products were shipped out of the state of Pennsylvania.

The Board contended ${ }^{9 x}$ that the activities of the Jones and Laughlin Corporation constituted a stream or flow of commerce, in which the Aliquippa plant was merely a focal point. The corporation, on the other hand, insisted ${ }^{92}$ that its production at Aliquippa was an intrastate manufacturing activity, that the ore and coal brought in from other states was stored in Aliquippa months in advance of their use, and that since the raw materials were converted into pig iron and the pig iron into steel products, separate and distinguishable items came into and went out of the state. The majority court declined to subscribe to either view of the situation, but held that even intrastate activities may fall within federal control when closely and intimately related to interstate commerce, and that the effect of a stoppage of the corporation's manufacturing operations by industrial strife would have a direct and immediate effect upon such commerce.

b) In the Fruehauf Trailer decision, the Court recited the findings of the Board and without further comment upon the matter of interstate commerce held that they were supported by the evidence.

${ }^{9 x}$ See Brief for Pl. in Error in Case No. 4I9, Oct. Term 1936.

${ }_{92}$ See Brief for Def. in Error in Case No. 4I9, Oct. Term 1936. 
c) In the Friedman-Harry Marks case, the Board's counsel undertook ${ }^{93}$ to prove not only the infiltration of the employer's business in interstate commerce but also the general interstate character of the men's clothing industry of which it was an integral part. The company ${ }^{94}$ stressed the locality of its manufacturing operations, but the Court deemed its discussion in the Jones and Laughlin case sufficiently pertinent to this case so as not to call for repetition. Although the minority court ${ }^{95}$ declared that all three manufacturing cases involved the same form of intrastate commerce, it used this case to stress its point. As urged by the company's briefs, it distinguished three separate stages in industry-the purchase of the raw materials, the manufacture of steel, trailers or clothing, and the distribution of the finished product. The effect of the intrastate production in the second stage upon the interstate commerce in the first and third stages was said to be far too remote and indirect to come within the control of Congress. The differences of opinion among the members of the court rested clearly upon different interpretations of economic interrelationships, and the accumulation of economic data in the briefs of counsel was obviously influential, if not conclusive.

d) In the Associated Press case, the Associated Press argued ${ }^{96}$ that its operations were not for profit, that it retained title to the news during interstate transmission, and that therefore it was not engaged in interstate commerce. The court held, however, that "Interstate communication of a business nature, whatever the means of such communication, is interstate commerce regulable by Congress under the Constitution." 97

e) In the Washington, Virginia and Maryland Coach Co. case, the argument ${ }^{98}$ that the regulation of the intrastate activities of the employer could not be separated from the regulation of its interstate activities was rendered immaterial by the findings of the Court with respect to the intrastate activities of the other employers. The Court gave its assurance that if a company engaged solely in intrastate commerce not affecting interstate commerce should be brought before the Court, it would not be held subject to the act.

The collective bargaining provisions of the National Labor Relations Act were brought within the Congressional commerce power by proof

93 See Brief for Petitioner in Cases No. 422 and 423 , Oct. Term 1936.

${ }_{94}$ See Brief for Respondent in Cases No. 422 and 423, Oct. Term 1936.

${ }_{95}$ See dissenting opinion in Labor Board Cases, 301 U.S. I, 76 (1937).

${ }_{96}^{6}$ See Brief for Petitioner in Case No. 365 , Oct. Term 1936.

97 Associated Press v. N.L.R.B., 30I U.S. 103, I28 (1937).

${ }_{98}$ See Briefs in Case No. 469 , Oct. Term 1936 . 
that industrial strife and strikes in the activities mentioned above result from an absence of collective bargaining, and cause a direct and proximate obstruction to the flow of interstate commerce. To establish this conclusion, the Board's Division of Economic Research prepared a section of the Jones and Laughlin case brief entitled, "The Burden and Injury to Interstate Commerce Resulting from Industrial Strife."'99 This commenced with a general statement on the paralyzing effect of strikes citing illustrations from expert testimony in the record and other nonlegal sources concerning the Steel Strike of I9I9, the Pacific Coast lumber strike of 1934 and the Chevrolet Motor Co. strike of I935. It referred also to a table of strikes which listed the number of strikes, employees involved and man-days of work lost in each year from I9I6 to 1936 . The statement continued with a discussion of the periods during which industrial strikes were particularly acute, of the industries seriously burdened by strikes, of certain notorious strikes, of the courts' recognition of an intention to burden interstate commerce by strikes, of the intervention of federal troops in railroad and steel strikes, of the federal commissions of inquiry in railroad, coal and textile strikes, of the federal conciliation service in I5,900 strikes involving sixteen million employees, of the federal regulation of labor relations in war industries, of the federal legislation on collective bargaining in the railroad industry, and of the rising tide of labor disputes for two years prior to the establishment of the first National Labor Board. These facts were interpreted to prove that strikes were increasing, that they obstructed the flow of interstate commerce, that many strikes were due to a refusal to bargain collectively, and that collective bargaining and government intervention to that end promoted industrial harmony and the continuity of interstate commerce.

This argument was heavily studded with references to the expert testimony of labor economists in the hearings before the Board, to additional reports of government agencies, and to writings of authorities on labor problems. The similar evidence presented by the labor economists in the early hearings and reprinted in the Bulletin No. I of the Board was cited for corroboration. . $^{\text {To }}$

The briefs for the employers discussed this economic material in three of the cases. In the Jones and Laughlin case, counsel for the corporation

99 See Briefs for PI. in Error in Case No. 4I9, Oct. Term 1936.

${ }^{200}$ In N.L.R.B. v. Fruehauf Trailer Co., 301 U.S. 49 (I937); N.L.R.B. v. Friedman-Harry Marks Clothing Co., 3 or U.S. 58 (1937); and Washington, V. \& M. Coach Co. v. N.L.R.B., 30r U.S. I42 (1937), the Board merely referred to the Jones \& Laughlin and to the Associated Press briefs for its argument that the act was a valid exercise of the federal power to protect interstate commerce from the burdens and injuries of industrial strife. 
devoted a section of their brief to the "Hypothetical Evidence" of the government, "none of which seemed to have any relevancy to the issues of the case." "ror

It is a defiance of reason and good judgment to argue that guesswork evidence of this character can bridge the distance between the discharge of 13 employees and the movement of interstate commerce..$^{102}$

The brief filed for the Associated Press criticized the Board's Bulletin No. $I$ in that the Bulletin merely demonstrated that strikes interrupt the continuity of production, not the continuity of commerce, and in that it failed to compare the size, permanency, or causation of obstructions resulting from non-collective action with all other possible obstructions to interstate commerce. ${ }^{x 3}$ The employer's brief did not attempt to supply such comparative data, except to state:

.... The evidence is not only ex parte, prepared by the proponents of the Act with a view to proving a doubtful point, but it is also inadequate .... . it fails utterly to distinguish between different industries, between unorganized and organized workers, or between overreaching employers and those who are more public spirited. Finally, this evidence completely ignores the fact, as the daily newspapers show, that strikes are quite as frequent in organized as in unorganized trades. ${ }^{\text {o4 }}$

The brief for the Friedman-Harry Marks Clothing Co. characterized the economic data of the Board as "rank hearsay, rumor, unqualified opinion and totally irrelevant, immaterial and unrelated matters of no probative force." ${ }^{\text {I05 }}$

The majority court, however, acknowledged the relevancy and probative value of the Board's economic data. Although the Chief Justice in the Jones and Laughlin decision, stated that the causation of strife by refusal to confer and negotiate was "such an outstanding fact in the history of labor disturbances that it is a proper subject of judicial notice and requires no citation of instances," ${ }_{106}$ he went on to mention some of the instances cited in the government's briefs, and he listed in a footnote several of the non-legal documents referred to by the government as well as the Board's Bulletin No. I. ${ }^{\mathbf{1 0} 7}$ The Court found that "experience has abundantly demonstrated" that the provisions for collective bargaining were often an essential condition of industrial peace; but the briefs

Ior See Brief for Def. in Error in Case No. 4I9, Oct. Term I936, at I9.

${ }^{202} \mathrm{Id}$. at $2 \mathrm{I}$.

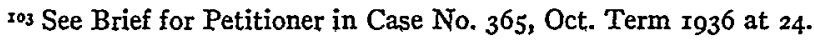

304 Id. at $6 \mathrm{r}$.

ros See Brief for Respondent in Cases No. 422 and 423 , Oct. Term 1936, at 26.

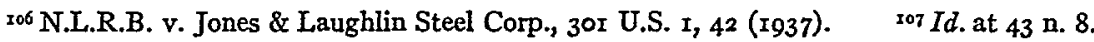


of the government made that experience seem abundant. The minority court found the "mass of testimony-largely irrelevant." The use of interpretative data was acknowledged even when not accredited.

In the determination of the other issues by the Court, such as the effect of compulsory collective bargaining in a newspaper establishment upon the freedom of the press, the existence of specific unfair labor practices, the adequacy of the Board's notices and hearings and the sufficiency of the evidence of a violation of the act, no economic material or expert opinions were discussed.

After these benedictory decisions, the Board's use of economic data varied considerably.

a) In the Pennsylvania and Pacific Greyhound cases, the primary issue was the power of the Board to order the disestablishment of a company union, and except for a footnote reference to economic documents on the advantage of employer's recognition over rival unions, the power was debated ${ }^{\mathrm{ro8}}$ and affirmed as a matter of the reasonable construction of the language of the act.

b) In the Santa Cruz and Consolidated Edison cases, the great issue was whether collective bargaining in a fruit packing company and a public utility affected interstate commerce. Considerable interpretative material was employed. There was introduced at the hearing before the Board evidence on the one hand that thirty-seven per cent of the total output of the Santa Cruz Fruit Packing Co. went into interstate commerce, that daily 3000 to 4000 cases were loaded onto various vehicles in a constant stream of loading and shipping, and that when the warehousemen struck, members of other locals of their union refused to haul the "hot" cargo and all shipments of the company's goods in interstate commerce stopped; ;09 and on the other hand it was shown that practically all of the fruits and vegetables were grown within the state and that the interstate shipments of the company were only a small part of its business. ${ }^{\text {xo }}$ In the Consolidated Edison case, there was evidence that the utility company supplied electric energy to interstate railroads, an interstate tunnel, trans-Atlantic piers and steamers, interstate telegraph and telephone systems, a transAtlantic radio service, an airport, lighthouses, post offices and various other federal buildings as well as that the company purchased large quantities of oil, coal and other supplies from other states. With such evidence, the court had little difficulty in indicating the effect of a strike in either

\footnotetext{
${ }^{108}$ See Brief for Petitioner in Case No. 413, Oct. Term 1937 at 25.

${ }^{109}$ See Brief for Respondent in Case No. 536 , Oct. Term $\mathbf{1 9 3 7}$.

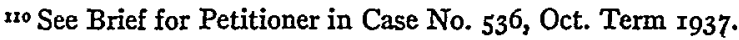


business upon interstate commerce. The Consolidated Edison case $\mathrm{e}^{\mathrm{Irx}}$ also involved the power of the Board to disestablish a collective bargaining agreement with an independent, A.F. of L. union. The briefs of the rival unions $^{122}$ contained many accusations and few facts; yet they conveyed the spirit of the A.F. of L.-C.I.O. conflict, and the court chose not to penalize the employer or the A.F. of L. union for the apparent preferences of the employer.

c) The Myers, ${ }^{\mathrm{rr3}}$ Newport $N e w s^{\mathrm{II} 4}$ and $F o r d^{\mathrm{Ir5}}$ cases raised purely procedural questions and no economic data were used in them.

d) The Mackay Radio case affirmed the power of the Board to reinstate workers who, in the rehiring after an unsuccessful strike, were discriminated against for their union activities. The opposite conclusion was reached in the Fansteel case with respect to sit-down strikers who were guilty of violence and the destruction of property. In the former case no interpretative facts were introduced, ${ }^{\mathrm{x} 6}$ whereas in the latter both the employer' ${ }^{\mathrm{II} 7}$ and the government's $\mathrm{s}^{\mathrm{Ir} 8}$ briefs referred to the statistics and the economic discussions of sit-down strikes. The court treated both cases, however, as abstract matters of statutory construction.

e) In the Sands ${ }^{129}$ and Columbian Enameling ${ }^{120}$ cases, the Board's counsel offered no economic data, and the court differed with the Board's interpretation of the narrative facts. The cancellation of a conference with United States Department of Labor conciliators was held not a refusal to bargain with employees; the closing of a plant upon the union's breach of a seniority agreement and the reopening with members of a rival union were held not a denial of collective bargaining; but the economic implications of the immediate situations were not presented. It may be that confidence in the Supreme Court's sympathetic understanding of labor relations, as illustrated in the Board's early cases, led to a neglect of economic data in the later ones, but the recent reverses indicate the continued need for such interpretative material.

${ }^{\mathrm{rx}}$ See Brief for Respondent in Case No. rg, Oct. Term I938.

${ }^{12}$ See Brief for Intervenor-Respondent and Brief for amicus curiae in Case No. I9, Oct. Term 1938 .

Ix3 Myers v. Bethlehem Shipbuilding Corp., 303 U.S. 4I (I938).

${ }_{114}$ Newport News Shipbuilding \& Dry Dock Co. v. Schauffler, 303 U.S. 54 (I938).

${ }^{315}$ Ford Motor Co. v. N.L.R.B., 305 U.S. 364 (1939).

${ }^{216}$ See Briefs in Case No. 706, Oct. Term 1938.

${ }^{127}$ See Brief for Respondent in Case No. 436, Oct. Term 1938.

${ }^{288}$ See Brief for Petitioner in Case No. 436, Oct. Term r938.

${ }^{129}$ See Brief for Petitioner in Case No. 274, Oct. Term 1938.

${ }_{220}$ See Briefs for Petitioner in Case No. 229, Oct. Term 1938. 
The use of economic data in these cases attests to its service in developing the law of collective bargaining-a service that is still unfinished. The Division of Economic Research of the National Labor Relations Board has already found occasion to prepare material showing the history of collective bargaining in many industries in order to cast light upon factors of company interference and domination. It has made specific studies of the profit and loss of businesses to determine the good or bad faith of an employer refusing to entertain the wage demands of his employees. It has also investigated such isolated problems as the effect of the presence of public citizens in the collective bargaining conference room. The numerous problems confronting employers and employees in their bargaining relationship are seldom subject to positive analysis or absolute determination; but the Board is required to make reasonable interpretations of all the obscure or conflicting circumstances, and the results of economic research are a guide worthy of its attention and recognition by the courts.

\section{LABOR LEGISLATION}

\section{HOURS}

The decisions of the United States Supreme Court on state legislation limiting the hours of work in private employment have reflected the battle between the Fourteenth Amendment to the federal Constitution and the police power of the states. ${ }^{121}$ In the Holden ${ }^{122}$ case, the Court undertook a detailed examination of the doctrines of due process of law and the police power in various fields of law. Upon the basis of the historical trends and precedents, it upheld the Utah eight hour law ${ }^{\mathrm{r23}}$ for men in mines, smelters and refineries as a police measure bearing a reasonable relation to the protection of health in a hazardous and unwholesome occupation. This doctrine was set back by the decision in the Lochner ${ }^{124}$ case invalidating a ten hour law $\mathrm{w}^{\mathrm{T} 25}$ for men in bakeries. In this uncertain situation-the regulation of hours for men-the Supreme Court considered a succession of statutes governing the hours of employment of women. The Oregon ${ }^{126}$ and Ohio ${ }^{127}$ ten hour laws and the California eight

${ }^{22}$ State legislation limiting hours of work in public employment was upheld by the Supreme Court as within the absolute power of the state legislature because no one has a right to public work without the consent of the state. Atkin v. Kansas, I9I U.S. 207 (I903).

${ }^{22}$ Holden v. Hardy, 169 U.S. 366 (r8g8).

${ }_{223}$ Utah I. 1896, c. 72, p. 219.

${ }^{124}$ Lochner v. New York, I98 U.S. 45 (1905).

${ }^{235}$ N.Y. L. I897, C. 4 I5, § Iro.

${ }^{126}$ Ore. L. I907, c. $200 \S$ I.

327 Ohio L. Igr I, p. 488. 
hour law for women ${ }^{\mathrm{r} 8}$ in a large and inclusive list of employments were upheld for the reason that women's physical structure and maternal functions made reasonable the special protection afforded her. In these decisions, ${ }^{129}$ the court devoted much attention to the effect of excluding many occupations and exempting certain workers upon the constitutional guaranty of equal protection of the laws. In each case it concluded that the law properly attacked the evil where it was most felt and proceeded cautiously to eliminate it step by step. After upholding both ten and eight hour laws for women, the Supreme Court again considered a ten hour law for men and in the Bunting ${ }^{3^{30}}$ case declared it a reasonable police regulation $^{\mathrm{r}^{3 \mathrm{x}}}$ for the preservation of health. Related to these cases on hours of work were the decisions of the Supreme Court upholding statutes prohibiting Sunday ${ }^{\mathrm{r} 32}$ and night work ${ }^{133}$ and requiring the posting of working schedules. ${ }^{134}$ All of these statutes were subjected to the tests of the Fourteenth Amendment, and they were sustained as valid expressions of the police power of the states only when the Court deemed them reasonably designed to promote safety and health.

Holden v. Hardy; Lochner v. New York.-The use of economic data in these cases bore a direct relation to the opposite conclusions reached. In the former case, the dangers to health in mining were deemed so well known that the government referred to them without citing any specific studies, ${ }^{135}$ and the court found that they had been recognized so long that they could not then be questioned. In the latter case, on the contrary, the conditions of the bakery industry had not been so well publicized, and the state's brief ${ }^{x_{3} 6}$ failed to present interpretative data whereas the employer's brief ${ }^{137}$ asserted that modern bakeries were machine-operated, well lighted, clean and free from dust. In an appendix, it recorded tables of trades showing their mortality rates, their susceptibility to the introduction of deleterious matters into the body, their exposure to conditions that interfere with nutrition and quotations from medical writers-

${ }^{238}$ Cal. L. Igrr, c. 258, amended Cal. L. I9r3, c. 352.

${ }^{129}$ Hawley v. Walker, 232 U.S. 7I8 (rgr4); Miller v. Wilson, 236 U.S. 373 (rgr5); Bosley v. McLaughlin, 236 U.S. 385 (Igr5).

${ }^{230}$ Bunting v. Oregon, 243 U.S. 426 (rgr7).

${ }_{33}$ Ore. L. $x_{913}$, c. roz, $\$ 2$.

${ }^{132}$ Hennington v. Georgia, 163 U.S. 299 (I896).

${ }_{333}$ Radice v. New York, 264 U.S. 292 (r924).

134 Riley v. Massachusetts, 232 U.S. 67 I (I9I4).

${ }^{233}$ See Brief for PI. in Error in Cases Nos. 261 and 264 , Oct. Term r8g8, at 6, 8-r2, 32.

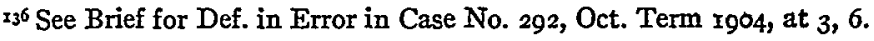

${ }^{237}$ See Brief for Pl. in Error in Case No. 292, Oct. Term 1904, at 18-45 and appendix. 
all to the effect that the baking industry was at least average in the wholesomeness of its working conditions.

The majority opinion referred expressly to the statistics regarding the relative wholesomeness of various occupations and adopted the argument that the law was designed to regulate conditions of employment among sui juris men in a private business, not dangerous in any real or substantial degree to the health of employees. ${ }^{\mathrm{x} 38}$ A minority opinion ${ }^{139}$ quoted from a book on diseases of workers and from an official report of the New York Bureau of Statistics of Labor to indicate the reasonable relationship between a limitation of hours and the health of bakers, but none of these authorities was supplied by the state's brief. Justice Holmes, in his separate dissent, openly declared that, "This case is decided upon an economic theory which a large part of the country does not entertain." ${ }_{\mathrm{I} 40} \mathrm{He}$ expressed his conviction that the constitution should not be interpreted to bar progressive legislation in his famous phrase: "The Fourteenth amendment does not enact Mr. Herbert Spencer's Social Statics." ${ }^{{ }^{4}}$ In his opinion the court did "not need research to show" ${ }^{42}$ that a reasonable man might think the eight hour law a proper measure on the score of health, but the research to the contrary, presented in the brief of the employer, apparently influenced a majority of the court to disagree with him.

Muller v. Oregon.-This case struck a high note in the use of interpretative data. Although the employer included no economic data in his brief, Mr. Louis D. Brandeis, appearing specially on behalf of the state, filed a monumental factual brief. ${ }^{43}$ With little discussion and a few legal citations he presented the legal principles concerning the liberty to purchase or sell labor, the reasonable restraint permitted under the police power, the necessity in legislation for a real or substantial relation to health and safety and the presumption of constitutionality rebuttable only on proof that the act is unreasonable, unnecessary and arbitrary; but he added a factual brief to demonstrate by facts of common knowledge, of which the court might take judicial notice, that there was reasonable ground for believing that a ten hour law for women promoted health, safety and the general welfare. The factual brief, compiled by a social worker, Josephine Goldmark, consisted of two parts. The first listed foreign and American legislation restricting the hours of labor of women. The second presented "The world's experience upon which the hours legislation was based."

\footnotetext{
${ }^{{ }^{8} 3^{8}}$ Lochner v. New York, I98 U.S. 45,59 (1905).

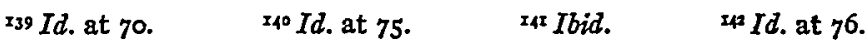

${ }^{243}$ See Brief for Def. in Error in Case No. ro7, Oct. Term 1907.
} 
It was composed of a brief statement of argumentative points, each followed by supporting quotations from official reports, the testimony of experts before official commissions and books on economics, medicine and factory legislation. The main argumentative points were labelled (I) Dangers of long hours; (2) Shorter hours the only possible protection; (3) General benefits of short hours; (4) Economic aspects of short hourseffect on output, effect on regularity of employment, adaptation of customers to shorter hours, incentive to improvements in manufacture, effect on scope of women's employment; (5) Uniformity of restriction; (6) Reasonableness of the ten hour day; and (7) Laundries-present character, bad effect upon health, safety and morals, irregularity of work. The theme of it all was that long hours of work were detrimental to the health of women primarily because of woman's peculiar physical characteristics, and that shorter hours of work produced general economic benefits.

The Court mentioned the brief in its opinion and inserted an epitome of it in the margin. Then it paid the following restrained tribute to such probative material:

The legislation and opinions referred to in the margin may not be, technically speaking, authorities, and in them is little or no discussion of the constitutional question presented to us for determination, yet they are significant of a widespread belief that woman's physical structure, and the functions she performs in consequence thereof, justify special legislation restricting or qualifying the conditions under which she should be permitted to toil. Constitutional questions, it is true, are not settled by even a consensus of present public opinion, for it is the peculiar value of a written constitution that it places in unchanging form limitations upon legislative action, and thus gives a permanence and stability to popular government which otherwise would be lacking. At the same time, when a question of fact is debated and debatable, and the extent to which a special constitutional limitation goes is affected by the truth in respect to that fact, a widespread and long continued belief concerning it is worthy of consideration. We take judicial cognizance of all matters of general knowledge. ${ }^{x 4}$

The interpretative data in the Brandeis-Goldmark brief was "worthy of consideration," in that it helped settle effectively the reasonableness of general hours legislation for women.

Hawley v. Walker; Miller v. Wilson; Bosley v. McLaughlin.-All of these cases repeated the use of the Brandeis-Goldmark brief on hour laws for women. The specific industry section was altered to cover millineries, dressmaking shops, telephone and telegraph systems, restaurants, hotels and hospitals as included in the new statutes. In the Bosley ${ }^{\mathrm{T} 45}$ case, there was appended, in its entirety, a publication of the United States Bureau

×41 208 U.S. 4I2, 420 (rgo8).

${ }^{245}$ See Brief for Def. in Error in Cases No. 362 and 363 , Oct. Term rgr4. 
of Education on the educational status of nursing, and the Court quoted from it at great length to justify the hours regulation of student nurses and the exclusion of graduate nurses. ${ }^{146}$ The briefs for the employers ${ }^{147}$ sought to upset the laws on the ground that they were discriminatory, but the Court found legal precedents in support of the step by step attack upon social evils.

Bunting v. Oregon.-In this case, Mr. Brandeis filed another of his historic hour-law briefs, ${ }^{18}$ this time revised to apply to the regulation of the hours of men. In outline and method it was the same as his other briefs. After the filing of this brief, Mr. Brandeis was elevated to the United States Supreme Court bench; Mr. Felix Frankfurter was substituted as counsel, and he filed a supplemental brief bringing the information in the original brief up to date. The extent to which this brief relied upon non-legal authorities and their nature are indicated by the thirty-five page list of sources under the headings: (I) Public documents; (2) Medical and laboratory; (3) Economic and social; and (4) Business experiments. ${ }^{19}$ The employer's counsel filed a reply brief complaining that the data in the Frankfurter brief did not pertain to the flour milling industry but related to other industries and other conditions such as overcrowded housing and improper living. ${ }^{\text {I50 }}$ Counsel cited, on his own part, two economic references to show that recent developments in the milling industry had made it compare favorably with other industries with respect to hazards to health.

The Court decided there were no facts proving the act unreasonable or arbitrary. This placed the burden of proof where it was always supposed to be-upon the party challenging the constitutionality of the statute. The Brandeis-Goldmark-Frankfurter brief had served its purpose well, and the Court required or at least suggested the adoption of its technique by the opposing side.

That does not mean that the progress of hours regulation by the states has been assured. The question of how short a work day will be regarded as reasonable is still unanswered. The question of whether the limitation of hours may be based on economic grounds independent of its bearing upon the protection of health is becoming increasingly important. In a recent case before the state Supreme Court of Pennsylvania, a factual

${ }^{146} 236$ U.S. $385,392^{2-93}$ (Igr5).

${ }^{147}$ See Brief for Pl. in Error in Cases No. 362 and $3_{3}$, Oct. Term rgr4.

${ }^{x 4^{8}}$ See Brief for Def. in Error in Case No. 38 , Oct. Term $19 x 6$.

149 See Supplemental Brief for Def. in Error in Case No. 38, Oct. Term rgr6.

${ }^{250}$ See Reply Brief for PI. in Error in Case No. 38, Oct. Term $x 916$. 
brief in support of a law, limiting the work week for all employees (with certain exceptions) to forty-four hours, stressed efficiency of production and distribution of purchasing power as well as health. ${ }^{\text {x5x }}$ That case unfortunately was decided on the technical ground of an improper delegation of legislative authority. ${ }^{152} \mathrm{New}$ advances in hours legislation will continue to require new economic briefs.

The immediate scene for such action has probably been shifted to the field of federal regulation. The federal statutes on hours of work have been few and there has been little litigation over them, ${ }^{153}$ but the recent

${ }_{15 x}$ Holgate Bros Co. v. Bashore, 33I Pa. 255, 200 Atl. 672 (I938). The state's brief made the following contentions, "I. The adjustment of working hours has been progressive with the development of the industrial revolution and has three major interests for society: (I) conservation of health; (2) greater efficiency of production; (3) better distribution of purchasing power. II. Hours of work are intimately associated with the susceptibility of workers to illness and accidents. III. A ceiling of hours must be proposed in order to prevent degradation of labor standards and purchasing power in the present era of depressed employment. IV. A reduction in hours to the 44-hour level does not necessarily involve greater production costs, because the shorter work-week is offset by increased hourly output. V. Pennsylvania industry is not exceptional but bears a direct relationship to industry elsewhere and will show similar trends. VI. The 44-hour week is not unreasonable. In fact, it sets a maximum higher than that of many states of the United States, and than that of many of the most progressive foreign countries." This 348 page brief contained 23 tables and charts in the text, 26 tables in the appendices, and I53 non-legal citations.

${ }^{252}$ Ibid.

I53 It was declared in I5 Stat. 77 (x868), that eight hours shall constitute a day's work for all laborers, workmen and mechanics employed by or on behalf of the government of the United States. The Supreme Court construed that to be merely a direction from Congress to the officers of the government (from principal to agent) that eight hours is deemed to be a proper length of time for a day's labor and not a prohibition against an agreement for a longer or shorter day. United States v. Martin, 94 U.S. 400 (1876). When the law was amended to prescribe a definite, binding work day, no one doubted its constitutionality and the Court has had no occasion to rule on it. The same has been our experience with statutes limiting the hours of service on public works or on public purchase contracts. The right of the government to spend its money or to contract on any terms it pleases has been undenied. The federal laws regulating hours in private employment in which the government has no interest of its own have been based on different principles. The act prohibiting work on railroads in excess of sixteen hours a day and for certain workers in excess of nine hours, was entitled "An act to promote the safety of employees and travelers." 34 Stat. I4I5 (rgo7), 45 U.S.C.A. \$§ 6I-4 (I928). This has been upheld as a valid exercise of the interstate commerce power with the acknowledgment that the length of hours of service has a direct relation to efficiency and the protection of life and property. B. \& O. R. Co. v. Interstate Commerce Comm'n, 22 I U.S. 6I2 (IgIr); United States v. A.T. \& S.F. Ry. Co., 220 U.S. 37 (r9Ir). The more general efforts to limit the hours of work on private employment by federal law have met a worse fate. The restriction of hours for the work of children, embodied in the federal child labor laws (discussed below), has been held unconstitutional as an incident to the general child labor regulation. Similarly, the limitations upon hours under the National Industrial Recovery Act and the National Bituminous Coal Comm'n Act have been held unconstitutional along with the regulation of wages and unfair trade practices (discussed below). 
enactment of the Fair Labor Standards Act ${ }^{154}$ presents once more the question of the validity of federal regulation of hours of work in private employment. In its blanket provision of a forty-four hour week (to be reduced to forty-two and then forty) for all employees, male and female, in practically all occupations engaged in interstate commerce or in the production of goods for interstate commerce, it raises issues broader than those ever before the Court. The need for economic data and the potentialities of its use in defending the hours provisions of this measure should be apparent from the account of its use in the hours cases discussed above.

\section{CHILD LABOR}

The United States Supreme Court has ruled that both the interstate commerce and the taxing powers of Congress do not embrace the regulation of child labor. In the Hammer case, ${ }^{155}$ it held unconstitutional a statute $^{\mathrm{x} 56}$ prohibiting the transportation in interstate commerce of commodities manufactured in mines or factories, in which within thirty days prior to the shipment, there were employed children under specified ages In the Bailey case, ${ }^{157}$ it held unconstitutional a statute ${ }^{\mathrm{r} 58}$ imposing a tax of ten per cent upon the net income of persons knowingly employing certain child labor.

Hammer v. Dagenhart.-In this case, the immorality and injuriousness of child labor were presented by the government with elaborate citations from reports of legislative committees and economic studies. ${ }^{159}$ The opposing brief ${ }^{160}$ countered with some evidence on the illness of non-workers as well as workers but its main argument was that such evils as existed in child labor did not remain in the product which alone was the subject of interstate commerce. The majority court held that the commerce power did not extend to the prohibition of the transportation of ordinary commodities, not obnoxious in and of themselves. In commenting on prior decisions prohibiting the transportation of lottery tickets, liquor, and prostitutes, the Court held that the element of transportation was indispensable to the evil in those cases but not so in this. The minority opinion $^{16 x}$ found the statute within the commerce power of Congress because

${ }^{{ }^{154}}{ }_{52}$ Stat. 1060 (1938), 29 U.S.C.A. 203 (Supp. I938).

155 Hammer v. Dagenhart, 247 U.S. 25I (1918).

${ }^{156} 39$ Stat. 675 (Igr6).

${ }^{257}$ Bailey v. Drexel Furniture Co., 259 U.S. 20 (I922).

${ }^{158} 40$ Stat. Ir38 (Igrg).

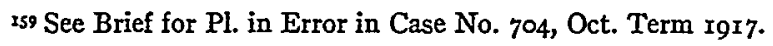

${ }^{160}$ See Brief for Def. in Error in Case No. 704, Oct. Term rgr 7.

16 $\pm_{247}$ U.S. $25 \mathrm{I}, 277^{-8 I}$ (19I8). 
it prohibited the carriage of goods in interstate commerce. Since Congress prohibited merely the act of shipment across state lines, it did not meddle with the internal affairs of the states. The commerce power had been used as a foothold to break up monopolies, to drive out state bank notes, and to prohibit the transportation of innocent articles sold through fraud; it might also be used to eliminate child labor. Both the majority and minority opinions were based more on theory and law than on economic data.

The government also sought to uphold the federal law because of the economic discrimination caused by variations in the state child labor laws. It illustrated the discrimination with economic data showing particularly a migration of cotton manufacturing plants from New England to the South. The opposing brief attempted to justify the variations in the state laws on the basis of variations in climate, age of child maturity, distribution of wealth and density of population; and at the same time it attempted to minimize the disparities on the ground that the states had independently regulated child labor pari passu with the extent to which they had become industrialized. The Court held, however, that the commerce power did not extend to the prevention of unfair competition.

The power of Congress to regulate child labor through its control over interstate commerce will again be presented to the Supreme Court under the Fair Labor Standards Act of 1938 . The possibility of utilizing economic data to obtain a reversal of the Hammer decision may be found in the discussion of the National Labor Relations Act cases and in the comment on the wage provisions of the Fair Labor Standards Act herein.

Bailey v. Drexel Furniture Co.-The government's brief ${ }^{162}$ argued that the Court had no power to question the motives of Congress in the exercise of its taxing power. This power had been employed before, notably in the tariffs upon certain imports and in the tax on oleomargarine, primarily to accomplish a social purpose rather than to raise revenue. The employer's brief ${ }^{\mathrm{x} 63}$ relied upon the record of Congressional debates to show that the tax bill was enacted in order to circumvent the decision of Hammer v. Dagenhart. In order to demonstrate that the tax had no reasonable relation to the raising of revenue and was not adapted to that end, it showed that the salaries of the persons employed in the child labor tax division of the Bureau of Internal Revenue for the years I9I9, I920 and I92I amounted to approximately $\$ 300,000$ while the receipts from the tax totalled approximately $\$ 27,000$. The Court found that the law regu-

${ }^{26 z}$ See Brief for Pl. in Error in Case No. 657, Oct. Term rg2r.

${ }^{263}$ See Brief for Def. in Error in Case No. 657, Oct. Term r92r. 
lated child labor by the use of a so-called tax as a penalty. Although there is no present disposition to reexamine the taxing power with respect to child labor, the intervening cases on social security taxes indicate what effective use might now be made of economic data in such a child labor case.

\section{WAGES}

The power of legislatures to regulate wages in private employment has long been argued before the Supreme Court. ${ }^{x 4}$ That body early upheld statutes governing the manner and time of wage payment; ${ }^{265}$ but in the hours law cases the Court took occasion to observe that the wages of the workers were not involved, implying that minimum wage laws might not be constitutional. ${ }^{66}$ In the Wilson case, a law reducing hours of work on railroads and prohibiting a reduction in wages was upheld as a temporary and emergency wage regulation in an industry affected with a public interest. ${ }^{167}$

The District of Columbia statute was the first regular minimum wage law to be discussed by the Supreme Court. ${ }^{168}$ It provided for the fixing of wages of women and minors on the basis of a cost of living adequate to maintain good health and morality. The majority court in the Adkins

${ }^{264}$ The right of a sovereign to stipulate the terms of its contracts or the contracts of its agents having been well established, the United States Supreme Court has never been called upon to approve the power of a legislature to set wages for public employment or for employment on public contracts. At the moment, the Court of Appeals for the District of Columbia is considering Lukens Steel Co. v. Perkins, No. 1368 , which is a challenge of a minimum wage determination under the Public Contracts Act, 49 Stat. 2036 (1936), 4r U.S.C.A. 35 (Supp. 1938).

${ }^{65}$ The United States Supreme Court approved a statute requiring redemption in cash of store orders or other evidence of indebtedness issued in payment for services rendered, Knoxville Iron Co. v. Harbison, I83 U.S. I3 (I9OI); Keokee Consolidated Coke Co. v. Taylor, 234 U.S. 224 (I9I4); a statute forbidding the payment of seamen's wages in advance, Patterson v. Bark Endora, I9० U.S. I69 (I903); a statute prohibiting contracts to pay miners employed at quantity rates upon the basis of screened coal instead of the weight of coal within the mine, McLean v. Arkansas, 2II U.S. 539 (Igog); Rail and River Coal Co. v. Yaple, 236 U.S. 338 (I9I5); and a statute regulating the assignment of wages, Mutual Loan Co. v. Martell, 222 U.S. 225 (rgIr).

${ }^{266}$ In Bunting v. Oregon, 243 U.S. 426 (IgI7), a provision for the payment of time and a half for overtime was carefully interpreted as a penalty against overtime work and not a minimum wage requirement.

167 Wilson v. New, 243 U.S. 332 ( $19 \mathrm{r} 7$ ).

${ }^{868}$ Justice Brandeis, having prepared the brief in defense of the Oregon minimum wage law shortly before he was appointed to the Supreme Court bench, did not participate in the hearing of that case and the Justices of the Court divided equally on the question of its constitutionality. Stettler v. O'Hara, 243 U.S. 629 (I9r7). Since the State Supreme Court had upheld that act, it remained in full force and effect, but the definitive opinion of the United States Supreme Court on minimum wage laws was not announced until the Adkins case was decided. 
cas $^{\mathrm{I} 69}$ found this an arbitrary infringement of liberty of contract because it was too vague, because it was unrelated to the nature or value of the work done, and because it discriminated against women workers. On the basis of this decision, the similar minimum wage laws of Arizona and Arkansas were held unconstitutional..$^{70}$

There intervened at this point two wage regulation cases growing out of comprehensive schemes to control fair trade as well as labor practices. The National Industrial Recovery Act ${ }^{171}$ provided for industrial codes establishing, among other things, maximum hours and minimum wages. The Supreme Court in the Schechter decision invalidated the act as an unconstitutional delegation of legislative authority because it empowered unofficial agencies to make law and because it failed to specify adequate standards for executive action. ${ }^{172}$ It expressly declared the wage and hour regulations too remotely connected with interstate commerce to fall within the power of Congress. Undaunted by this decision, Congress enacted the Bituminous Coal Conservation Act of $1935^{173}$ which provided for a bituminous coal code and incorporated, among various trade and labor regulations, the minimum wages to be set by a collective bargaining contract. Coal operators were induced to accept the code by an exemption of ninety per cent of an excise tax placed upon all coal mined. In the Carter case, ${ }^{174}$ the Supreme Court declared the wage and hour provisions of this act an unconstitutional effort to regulate local matters as well as an improper delegation of legislative authority to private individuals. In both general plans to regulate trade and labor practices, the labor provisions were singled out for special treatment and declared to be beyond the power of Congress.

When in the depression year I933 the State of New York desired a minimum wage law, it sought to take advantage of certain implications in the majority opinion in the Adkins case; its statute therefore provided that wages both less than the fair and reasonable value of services rendered and a sum sufficient to meet the minimum cost of living for health were oppressive and unreasonable and should be replaced by a minimum "fair wage," to be set on a basis fairly and reasonably commensurate with

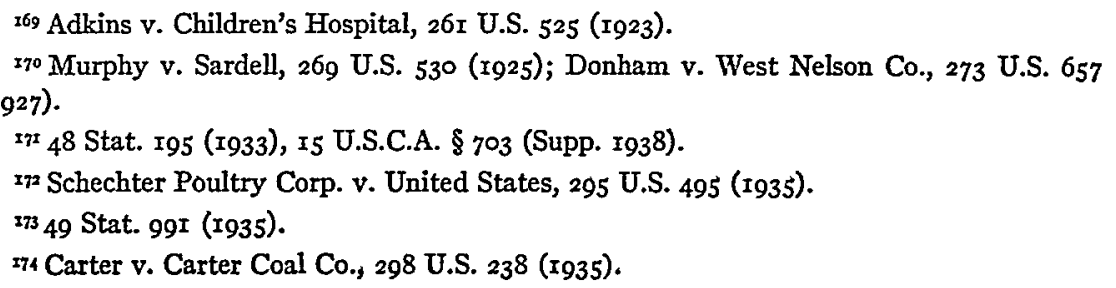


the value of the services rendered, ${ }^{175}$ In the Morehead case, ${ }^{176}$ however, the Supreme Court found that this retained all of the vulnerability of the District law. Within the next year, in the West Coast Hotel case, ${ }^{177}$ the Supreme Court reversed itself. In passing upon the Washington minimum wage law, ${ }^{178}$ which had the same standard (the necessary cost of living to maintain health) as the District law adopted, the Court found the law a reasonable exercise of the legislature's police power, and expressly overruled the Adkins decision. The use of economic data in the minimum wage cases well illustrates the possibilities of that technique in an atmosphere charged with strong convictions.

Adkins v. Children's Hospital.-In this case, the brief, ${ }^{179}$ prepared by Mr. Felix Frankfurter and Josephine Goldmark, followed the prototype of the Brandeis-Goldmark brief; it attempted to demonstrate, by presenting numerous quotations from American and foreign non-legal authorities in support of the measure, ${ }^{780}$ that the reasonableness of the legislation was a matter of common knowledge. It first sought to prove the successful working of minimum wage legislation and emphasized that $(x)$ the unfair depression of the lowest wage level of women workers was lessened or removed; (2) industrial efficiency of both employers and employees was stimulated; (3) competing employers were benefited; (4) an influence toward industrial peace was created; (5) the legislation was effective and fair, and that (6) prophecies of evil were disproved by actual experience: ( $a$ ) business was not hurt, but helped, (b) minimum wages did not become maximum, and (c) displacement of workers was inconsiderable. Its second part listed the minimum wage laws of this and foreign countries. The third section discussed the need for minimum wage legislation for women in the District of Columbia and the whole United States and presented expert testimony on the wages of women, the minimum standard of living and the evils of inadequate wages.

Lest the Court heed the sentiment quoted in favor of the act, counsel for the employer quoted eminent officials of the A.F. of L., the National Women's Party, the National Women's Suffrage Association, the Equal Rights Association and the Federation of Business and Professional

${ }^{75}$ N.Y.L. I933, c. 584 .

${ }_{756}$ Morehead v. People ex rel. Tipaldo, 298 U.S. 587 (1936).

${ }_{777}$ West Coast Hotel Co. v. Parrish, 300 U.S. 379 (1937).

${ }^{178}$ Wash. L. 1913, c. 174.

${ }^{279}$ See Brief for United States in Cases No. 795 and 796, Oct. Term I922.

${ }^{180}$ See Brief for Def. in Error in Case No. I07, Oct, Term r9o7. 
Women's Clubs to show that there was no real desire for minimum wage laws for women. ${ }^{\text {.8x }}$

The majority court acknowledged the "large number of printed opinions approving the policy of the minimum wage" but added "our own reading had disclosed a large number to the contrary." ${ }^{82}$ It found the "mass of reports and opinions of special observers and students on the great benefits of minimum wage legislation .... interesting but only mildly persuasive." ${ }^{283}$ To the minority justices, however, the factual material in the government's brief was "very respectable authority." 84 and "a very remarkable collection of documents" ${ }^{\prime 85}$ amply proving the reasonableness of the legislation.

The brief for the employers also objected to the uncertainty of the minimum wage standards in the act. ${ }^{186}$ It presented the different minima determined for mercantile, hotel and laundry workers and observed that the same woman shifting from one employment to another could not require such different wages on the basis of her health or morality. It stressed the differences in economic circumstances among women and noted that no minimum was needed by the woman of adequate means who worked for the joy of working.

Moreover the standards referred to the needs of the employee and ignored the necessities of the employer in that they required no service of equivalent value from the employee. The majority court accepted this criticism despite, or perhaps because of, the lack of economic data to explain its full significance.

Morehead v. Tipaldo.-The factual brief of the State of New York ${ }^{187}$ presented statistical evidence and corroborative opinion from numerous government publications and economic treatises to prove that since the Adkins decision, there had appeared in industry an ever increasing number of female breadwinners, that the depression of r930 had brought a clearer realization of their maladjustments and that remedial action which formerly may have seemed oppressive now appeared necessary and wise. A brief filed by the Corporation Counsel of the City of New York supplemented this with statistics from the records of local public agencies to show that the municipality had been compelled to augment earnings with

\footnotetext{
${ }^{18 r}$ See Brief for Def. in Error in Cases No. 795 and 796, Oct. Term, 1922.

${ }^{182}$ Adkins v. Children's Hospital, 26I U.S. 525 (I923).

${ }^{283} \mathrm{Id}$. at 560 .

${ }^{884}$ Id. at 564 (Chief Justice Taft). $\quad{ }^{885} \mathrm{Id}$. at 570 (Justice Holmes).

${ }^{286}$ See Brief for Def. in Error in Cases No. 795 and 796, Oct. Term I922.

${ }^{187}$ See Brief for Pl. in Error in Case No. 838, Oct. Term I935, at I-40 and appendix.
} 
relief, thereby subsidizing low wage employers and that many of the prostitutes of New York had had antecedent employment at very low wages. ${ }^{\text {188 }}$

The employer's brief ${ }^{189}$ responded that these facts added nothing new to the data presented in the r, 106 page factual briefs in the Adkins case.

The majority court observed that although the State of New York referred to changes in conditions since the Adkins case, the factual background stated in the law was the same as recited in an emergency bill, which had been vetoed and which attempted to establish a minimum wage for men as well as women. The facts of need, it inferred, were the same for men and women; hence the regulation of the latter and not the former was discriminatory. The Court said nothing of the testimony submitted as to the peculiar bargaining weaknesses of women. Chief Justice Hughes, in his dissent, acknowledged the data submitted from the reports of the Women's Bureau of the United States Department of Labor showing discrepancies in the earnings of men and women performing identical work, the unorganized state of working women and the relative weakness in their bargaining power. He mentioned further the data from the New York State Department of Labor and the Emergency Relief Bureau of New York City on the burden upon taxpayers caused by the failure to pay wages commensurate with value of services, and he found the necessity for taking remedial measures "strikingly exhibited in the brief filed by the Corporation Counsel of the City as an amicus curiae." ${ }^{390}$ In his judgment, the Court was "not at liberty to disregard these facts," but "must assume that they exist."

A. L. A. Schechter Poultry Corp. v. United States.-The government brief $^{\mathrm{rg2}}$ maintained that the object of the N. I. R. A. was to relieve interstate commerce of obstructions caused by the depression. It presented factual evidence of the great decline in prices, the downward spiral of production and the fall in wages and employment, and it argued that a reverse in this process was needed to stimulate recovery and prosperity. It expressly stated that the emergency did not create a new Congressional power but merely occasioned the use of the interstate commerce power to relieve commerce of the tremendous burdens and restrictions upon it,

${ }^{188}$ See Brief of Corporation Counsel of New York City as amicus curiae, in Case No. 838 , Oct. Term r935, at 2-I3.

${ }^{189}$ See Brief of Def. in Error in Case No. 838, Oct. Term 1935, at Io-r3.

${ }^{190} 298$ U.S. 587,627 (1936).

${ }^{991}$ Ibid.

${ }^{192}$ See Brief for Def. in Error in Cases Nos. 854 and 864 , Oct. Term 1934, at 30-93 and appendix. 
and that without federal action, the burdens and restrictions could not be lifted. The Schechter brief cited a Brookings Institute report to prove that the N.R.A. did not promote prosperity by raising wages before prices. The Court held that the grave national crisis did not create or enlarge constitutional powers and therefore did not authorize the effort to fix hours and wages.

The government's theory that the live poultry code came within interstate commerce rested on the facts that the New York poultry market imported nearly all of its fowl from other states and set prices for markets in other states, and that all of the fair trade practices in the code, as well as the setting of minimum wages and maximum hours, promoted stability of prices which in turn facilitated the free flow of commerce. The relationship of the New York market to prices in other states was indicated by tables and charts. The labor provisions were also linked with interstate commerce by statistics from government reports and economic texts on the number of strikes due to wage and hour disputes and the loss of commerce resulting therefrom. The brief for Schechter ${ }^{193}$ stressed the fact that the activities regulated were intrastate activities, and it attacked the government's theory of Congressional control over acts "affecting" interstate commerce by observing that the logical consequence of such a theory was a planned economy which would destroy our theory of government.

The Court accepted the view that the transactions regulated by the code were intrastate on the ground that the poultry, though imported, had been commingled with the mass of property within the state and had come to rest. The Court argued that if wages and hours could be held to affect interstate commerce because of their effect upon prices, so could all other items of cost, and everything in industry would be subject to the interstate commerce power.

On the problem of the proper delegation of legislative power, the argument was almost entirely legal. The Court held that the legislative policy to rehabilitate industry and to promote recovery was too vague and that the standard of "fair competition" was not known to the law as were the standards of "unfair trade" and "public convenience and necessity." The delegation of law-making powers to voluntary trade associations was held inconsistent with the duties of Congress and the delegation of such powers to the President was inadequate because of the lack of definite standards and the failure to require sufficient findings.

Carter v. Carter Coal Co. - Economic data were utilized throughout the ${ }_{93}$ See Briefs for Pl. in Error, in Cases Nos. 854 and 864, Oct. Term I934, at 97, 144, 198. 
course of this case. In its first pleading, ${ }^{194}$ the government made a separate defense of economic facts relating to the amount of coal shipped and used in interstate commerce, the depression of the coal industry, the effect of cut-throat competition upon wages and the obstruction of commerce by strikes. At the trial of the case, the government introduced a great deal of expert testimony, supported by references to many economic studies and government reports, on the facts alleged in this answer. The coal operators, on their part, introduced additional expert testimony similarly supported by the experiences and studies of the industry.

The briefs of the coal operators ${ }^{195}$ and the government ${ }^{\mathrm{xg}}$ engaged in an economic debate over the nature of the industry's ills and the reasonableness of the proposed remedies. The non-legal, yet technical, character of this discussion can be observed from the manner in which they dealt with certain questions of fact. (a) Was the industry suffering from chaotic competition? The government attributed the industry's condition to multiple causes-inelasticity of demand, high proportion of wage costs with wage cutting as the chief form of competition, high costs of shutting down uneconomical mines, planless production-all calling for the regulation proposed. The operators attributed its condition basically to overcapacity which was unaffected by the proposed controls. (b) Were the low prices and wages a sign of demoralization in the industry? The operators claimed they were a normal readjustment from the abnormally high war and post-war prices and wages. The government rebutted this view by criticizing the statistics upon which it was based, claiming that the operators erred in such ways as using a wholesale price index of all commodities instead of a cost of living index and comparing wage rates in one industry with earnings in another. (c) Was the movement of business from the North to the South a dislocation of commerce? The government claimed it was because it was accompanied by wage cutting, price cutting, stoppages and shut-downs. The operators claimed it was not because the total amount of commerce was undiminished and the shift represented the normal flow of business from one operator to another due to competition. (d) Did labor disputes obstruct interstate commerce? The government cited the strikes of I906, I908, I9I0, I9I2, I9I9, I922 and I927. It told of the I69,000 on strike in eight states in I927 and of the drop in coal shipments in Illinois from ten million tons a month to a negligible quantity. It explained the stoppages in 1928 and 1932 pend-

\footnotetext{
${ }_{194}$ See Brief for United States in Cases Nos. 636 and 651, Oct. Term 1935.

${ }_{95}$ See Brief for Def. in Error in Cases Nos. 636 and $65 \mathrm{r}$, Oct. Term r935.

${ }^{296}$ See Brief for United States in Cases Nos. 636 and 651 , Oct. Term 1935.
} 
ing the settlement of disputes in unorganized areas as chronic stoppages to be expected as long as part of the industry remained unorganized and refused to bargain collectively. The operators argued that in all the labor disputes between 1924 and 1933 there was a loss of only nine to ten days per man per year and that at no time since I922 had consumers been forced to go without coal as a result of a strike. (e) Were the bituminous coal operators engaged in interstate commerce? The government showed that approximately eighty-five per cent of the coal was consumed in states other than those in which it was mined. The operators showed that forty-two per cent of the coal was sold locally, that many producers were engaged exclusively in local trade and that mining itself was a local process separable from the transportation of coal. ${ }^{x 97}$

The majority court alluded to these facts only incidentally. It defined interstate commerce as "intercourse for the purpose of trade" and held mining to be intercourse for the purposes of production rather than trade. Controversies over labor relations were local controversies over local ills. "Such effect as they may have upon commerce, however extensive it may be, is secondary and indirect."I98 The mandatory imposition of hours and wages by a contract between a majority of producers and a majority of labor representatives upon a dissentient minority was found to be an improper delegation of legislative authority to private persons to regulate the business of their competitors. This was deemed an intolerable and unconstitutional interference with personal liberty and private property.

West Coast Hotel Co. v. Parrish.-No factual brief was filed in this case. The majority court noted this, but held "there is no reason to doubt that the State of Washington has encountered the same social problem as elsewhere." ${ }^{\prime 99}$ The Court revealed a thorough acquaintance with all data submitted through such briefs in former cases and with "recent economic experience."

We may take judicial notice of the unparalleled demands for relief which rose during the recent period of depression and still continue to an alarming extent despite the degree of economic recovery which has been achieved. It is unnecessary to cite official statistics to establish what is of common knowledge through the length and breadth of the land. ${ }^{200}$

${ }_{97}$ Briefs filed by amici curiae merely augmented the dispute with similar evidence. The briefs for the States of Ohio, Illinois, Pennsylvania, Washington, Kentucky and New Mexico raised the cry that they were helpless to regulate the industry in their separate jurisdictions, and needed the federal act to save their coal producers from disastrous competition.

${ }^{198} 298$ U.S. 238,309 (1936).

${ }_{999} 300$ U.S. 379,399 (1937). $\quad 200$ Id. at 399 . 
Such statistics, however, had been before the court in the Morehead case and were again before it in the pending social security cases. ${ }^{20 x}$ On the basis of such information, the Court interpreted the minimum wage law as an effort on the part of the community to avoid giving a subsidy to unconscionable employers. The other reasons for upholding the law as a reasonable exercise of police power it found in the minority opinions of the Adkins case.

The enactment of the Fair Labor Standards Act of 1938 has presented a number of new issues with respect to the power of Congress to set minimum wages for both men and women in industries producing goods for interstate commerce. Although the personnel of the Supreme Court has recently been changed and the interstate commerce power of Congress has been broadly interpreted, these are merely auspicious circumstances for the consideration of the social implications of the new law. It may be relatively simple to demonstrate that the wage and hour law has a reasonable relationship to the health of male workers, the harmonious functioning of industry and the general welfare of the community. Such a factual brief has been prepared for hours laws for men, and just as was done for the laws on women, the material may be revised to show the reasonableness of wage laws for men. It may be more difficult to demonstrate the proximate relationship between the regulation of wages and interstate commerce. The reasoning of the National Labor Relations Act cases may be relied upon in a factual showing of the interruptions to interstate commerce due to industrial strife over wages. Far more strikes have been caused by disputes over wages than by struggles over the right to bargain collectively. The interstate ramifications of specific industries and the effect of stoppages in production upon interstate commerce can be presented as graphically for wage arguments as they have been for bargaining disputes in the National Labor Relations Act cases.

It is possible, however, that the occasion of the Fair Labor Standards Act before a liberal court may be taken to obtain a broader conception

${ }^{202}$ A discussion of the social security cases has been omitted from this article for want of space. In Carmichael v. Southern Coal \& Coke Co., No. 724, Oct. Term I936, 30r U.S. 495 (I937), and Steward v. Davis, No. 837, Oct. Term I936, 30I U.S. 548 (I937), briefs for the state of Alabama and the United States contained scholarly statements of the economics of unemployment and unemployment relief. They both expressly relied also upon the economic brief submitted in Chamberlin v. Andrews, Cases No. 49, 50, 64, Oct. Term I936, 299 U.S. 5 I 5 (I936) in which the Supreme Court affirmed per curiam the state court decision upholding the New York Unemployment Compensation Act. Economic data on old age dependency and annuities were presented in Railroad Retirement Board v. Alton R. Co., Case No. 566, Oct. Term 1934, 295 U.S. $33^{\circ}$ (1935) and in Helvering v. Davis, Case No. 910, Oct. Term 1936, 301 U.S. 619 (1937). 
of the commerce power of Congress. At least with respect to the shipment of goods and the transmission of information in the channels of interstate commerce, it may be argued that the power of Congress is plenary so that the physical shipment or transmission may be prohibited on the basis of any standard deemed reasonably related to the public welfare. That standard may be local or international, a matter of production or a matter of trade, a quality of the goods transported or an intangible public policy; it need not bear any causal relationship to interstate commerce as long as it is applied only in the realm of interstate commerce. To maintain such an interpretation of the commerce power of Congress, it may be helpful to present factual material on the "economic conditions which have supervened" ${ }^{202}$ since the adoption of the constitution and the formulation of the early judicial decisions on the commerce power. Those conditions include the increasing interdependence of the various parts of our country, the increasing unity of certain aspects of our economy, the increasing tendency of business to form interstate combinations and the increasing federal assumption of the burdens of "local" relief, social security, employment, rural rehabilitation, and the conservam tion of natural resources. It may be that those conditions have been in existence for some time, but the realization of them has "supervened" the consciousness of our people only recently. The liberal Supreme Court may take judicial notice of such data if they are presented fully enough to appear to be common knowledge or if they are revealed to be the factors that Congress reasonably considered in the enactment of the Fair Labor Standards Act. On the basis of such data, the Supreme Court may uphold the Act and propound the plenary power of Congress over interstate commerce.

This review of the use of economic data in labor cases has been limited to the briefs and recorded arguments before the United States Supreme Court and has been confined to civil actions and substantive or jurisdictional issues. It may well be that in criminal cases or cases involving procedural matters economic data may have less utility. It is not true, however, that the usefulness of such data is confined to cases at the level of the Supreme Court or to appellate briefs. In the Carter Coal Co. case, the essential facts were alleged in the initial pleading. In the National Labor Relations Act cases, the economic data were presented at the first administrative hearing. In the Muller case, the interpretative material was presented for the first time before the Supreme Court merely because

${ }^{202}$ West Coast Hotel Co. v. Parrish, 300 U.S. 379, 390 (I937). 
the case arose on demurrer. In order to take advantage of the protective presumptions that accompany the findings of the lower courts, it would appear to be prudent to introduce economic data at the earliest possible moment.

The form in which economic data have been presented has varied. The Brandeis-Frankfurter-Goldmark briefs were factual briefs appended to legal briefs and this dual form has been adopted by many attorneys. The National Labor Relations Board briefs, however, integrated the economic data into the legal argument in one brief. This has been the most common form since most briefs have not had enough economic data for separate treatment. The Carter Coal Co. briefs had both a special section devoted to the facual defense and an admixture of economic data with the legal material. The relative merits of these forms depend probably upon the assimilability of the economic data in the legal argument.

The nature of the economic data introduced has also varied widely. It has grown in complexity from the simple references to common knowledge in the Holden case to the great compilation of world experience in the Muller case. It has risen in authority from the few industry monographs in the Lochner case to the many government and scientific research reports in the Carter Coal Co. case. It has ranged in formidability from the unsupported assertions of fact in the Senn case to the elaborately documented argumentation in the Jones and Laughlin case. From the time of the early labor cases at the end of the last century to the present time, economic research, particularly in the field of labor problems, has expanded tremendously and this development has been reflected in the economic data used in labor cases.

The effect of the economic data reported above is most difficult to appraise. For want of a device to read the minds of judges, it is impossible to declare dogmatically that certain data were responsible for certain decisions. The Supreme Court opinions bear many grateful acknowledgments of the economic data submitted and it seems certain that no cause has been penalized for the introduction of such data whereas many causes have been helped. In those cases above in which one party used economic data and the other failed to or used it only incidentally, victory went to the former sixteen ${ }^{203}$ times and to the latter

${ }^{203}$ Coronado Coal Co. v. United Mine Workers, 268 U.S. 295 (1925); Muller v. Oregon, 208 U.S. 4I2 (Ig08); Lochner v. New York, 198 U.S. 45 (Ig05); Hawley v. Walker, 232 U.S. 718 (rgI4); Miller v. Wilson, 236 U.S. 373 (19I5); Bosley v. McLaughlin, 236 U.S. 385 (19I5); Senn v. Tile Layers Protective Union, 301 U.S. 468 (I937); New Negro Alliance v. Sanitary Grocery Co., 303 U.S. 552 (1938); N.L.R.B. v. Jones \& Laughlin Steel Corp., 301 U.S. I 
only three ${ }^{204}$ times. This may have been sheer coincidence, but it strongly suggests a causal relationship. A more intimate examination of the record corroborates the conclusion that the use of economic data has been effective in labor cases.

The use of economic data seems well assured for the future. As long as courts seek the reasonableness of legislation in a changing economic order, as long as laws require an effect upon interstate commerce or as long as attorneys must prove an intent to accomplish an economic objective, there will remain a need for economic data.

(I937); N.L.R.B. v. Fruehauf Trailer Co., 30I U.S. 49 (I937); N.L.R.B. v. Friedman-Harry Marks Clothing Co., 30r U.S. 58 (1937); Washington, Virginia \& Maryland Coach Co. v. N.L.R.B., 301 U.S. 142 (1937); Associated Press v. N.L.R.B., zor U.S. I03 (1937); Consolidated Edison Co. v. N.L.R.B., 304 U.S. 555 (r939); Santa Cruz Fruit Packing Co. v. N.L.R.B., 303 U.S. 453 (1938); Bailey v. Drexel Furniture Co., 259 U.S. 20 (I922).

204 Adkins v. Children's Hospital, 26I U.S. 525 (r923); Morehead v. People ex rel. Tipaldo, 298 U.S. 238 (1935); Schechter Poultry Corp. v. United States, 295 U.S. 495 (x935). 